\title{
Fotografinès Holokausto reprezentacijos Lietuvos istoriografijoje: bendra charakteristika ir probleminiai aspektai
}

\section{Šarūnè Sederevičiūtè}

Vilniaus universitetas

Universiteto g. 7, LT-01513 Vilnius

sarune.sedereviciute@jmuseum.lt

— Straipsnyje pristatomas pilotinis tyrimas, kuriuo siekta ištirti Holokaustą Lietuvoje reprezentuojančių istorinių fotografijų charakteristiką bei panaudojimo būdus lietuviškoje ir užsienio istoriografijoje taip siekiant išsiaiškinti problemines temas tolesnėms Holokausto fotografijos Lietuvoje studijoms. Esama padètis rodo aiškų istorinių tyrimų, skirtų fotografijų atsiradimo ir vẻlesnès sklaidos aplinkybėms nustatyti, poreikị. Apie paviršutinišką fotografinių istorinių šaltinių traktavimą liudija vyraujantys tiek abstraktūs, tiek trumpi ar net klaidingi nuotraukų prierašai, vengimas ivvardyti originalias vaizdu atsiradimo aplinkybes, jų autorius, o neretai nurodyti šaltinị. Taip pat nèra tvirtai susiformavusio lietuviško Holokausto vizualikos kanono. istorija. 
Šiuolaikinės visuomenės tyrinètojai kaip vieną iš jos bruožų dažnai apibrèžia analogų praeityje neturintị vaizdụ ,tvaną“ visose gyvenimo srityse, įskaitant ir istorijos pažinimą ${ }^{1}$. Plačiai pastarajį reiškinį išnagrinèjęs kanadiečių edukologas Markas Mossas teigia, kad, aiškinant visuomenei praeiti, fotografija nepaprastai svarbi, mat jau nuo pat šios medijos atsiradimo nuotrauką dèl gebėjimo autentiškai atkurti regimajji pasauli imta sieti su tikrove 2 . Taip pat šiandien pripažistama, kad Holokaustas yra vienas gausiausiai Europos mastu fotografuotų moderniosios istorijos ịvykių, ir būtent nuotraukos tapo pagrindinemis istorijos apie ši îvyki pasakotojomis plačiajai visuomenei, vadinasi, atlieka svarbų vaidmenị konstruojant kolektyvinę atmintį่3. Yra net teigiančių, kad kone maniakiškas nacių dėmesys vizualinei dokumentacijai iš dalies lėmè ir vèlesnị Holokausto unikalumo suvokimą4. Juk fotografuoti reiškia ir suteikti svarbą. Be to, fotografijos teoretikai pastebi ir tai, kad nuotraukų reikšmè priklauso ne tiek nuo jų turinio, kiek nuo interpretacijos, kurią formuoja valstybè, archyvas, muziejininkas, kuratorius, istorikas ir t. t. ${ }^{5}$

Šių ir panašių svarstymų fone kyla nemažai „vietinès reikšmès“ klausimu - o kokios viešumoje skelbtos fotografijos perteikia Holokaustą Lietuvoje? Ar galime įžvelgti vizualinį kanoną ikoninių fotografijų, sakančių „o taip atrodè Holokaustas Lietuvoje“, seriją? Ar keitėsi, o jeigu taip - tai kaip, tų pačiu nuotraukų interpretacijos?

Norint atsakyti ị šiuos klausimus, šikart buvo nuspręsta susitelkti ì nacių okupacijos laikotarpio (1941 m. birželis - 1944 m. rugpjūtis) fotografijas iš Lietuvos, publikuotas tiek mokslinėje, tiek populiariojoje vietinėje ir užsienio literatūroje. Taigi pagrindinis pristatomo tyrimo tikslas - ištirti

1 Humanitariniuose ir socialiniuose moksluose susidomëjimas vizualikos poveikiu visuomenei paprastai apibūdinamas kaip vizualinis posūkis, plačiau žr. Jolita Mulevičiūtè, Besotis žvilgsnis. Lietuvos dailè ir vizualioji kultūra. 1865-1914, Vilnius: Lietuvos kultūros tyrimų institutas, 2012.

2 Mark Moss, Toward the Visualization of History: The Past as Image, Plymouth: Lexington Books, 2010, p. 106-107.

3 Tą sutartinai teigia: Mariene Hirsch, „Surviving Images: Holocaust Photographs and the Work of Postmemory“, in: Visual Culture and the Holocaust, ed. Barbie Zelizer, London: Rutgers University Press, 2001, p. 218; Janina Struk, Photographing the Holocaust: Interpretations of the Evidence, London: I. B. Tauris, 2004, p. 213; Susan A. Crane, „Choosing Not to Look: Representation, Repatriation, and Holocaust Atrocity Photography“, in: History and Theory, 2008, Nr. 47, p. 309; Michael F. Bernard-Donals, Forgetful Memory: Representation and Remembrance in the Wake of the Holocaust, State University of New York, 2009, p. 58.

4 Janina Struk, op. cit., p. 214.

5 Ibid., p. 13. 
Holokaustą Lietuvoje reprezentuojančių fotografijų charakteristiką bei panaudojimo būdus lietuviškoje ir užsienio istoriografijoje.

Tyrimas ne baigtinis, bet pilotinis, siekiant išsiaiškinti problemines temas tolesnèms Holokausto fotografijos Lietuvoje studijoms. Išsikelti ir šie uždaviniai: 1) remiantis teorine literatūra apsibrèžti problemines Holokausto fotografijos sritis ir pagal jas susisteminti tyrimo šaltinius pasitelkiant konkrečias analitines kategorijas; 2) palyginti užsienio ir Lietuvos leidiniuose skelbtas fotografijas; 3) nustatyti ir aptarti pagrindinius probleminius Holokaustą Lietuvoje atspindinčiu fotografijų publikavimo leidiniuose aspektus.

Pagrindinę tyrimo šaltinių bazę sudaro du blokai. Pirma, tai visi Lietuvoje išleisti neverstiniai iliustruoti spaudiniai, pasakojantys apie Holokaustą Lietuvoje (jų 20). Antra, 16 užsienio leidinių - verstinių ar originalo kalbomis - ta pačia tema. Šiuo atveju pasirinkti ne visi, o tyrimo autorei pasiekiami dèl praktinių aplinkybių ${ }^{6}$. Siekiant lygiaverčio palyginimo, neimtos publikacijos, skirtos itin siauriems lokalia ar ịvykio prasme Holokausto epizodams. Taigi remtasi tais leidiniais, kurie atskleidžia Holokaustą, Lietuvos, žydų ir Antrojo pasaulinio karo istoriją.

Jau kaupiant tyrimo šaltinius, paaiškejjo, kad dauguma istoriografijos apie Holokaustą Lietuvoje neturi jokių iliustracijų arba jos visiškai nesusijusios su aptariamu laikotarpiu, tad galutiniai tyrimo ištekliai ne itin dideli - susistemintos 306 nuotraukos (191 iš Lietuvos, 115 iš užsienio leidinių). Pasitelkti ir papildomi šaltiniai - sovietinè iliustruota istoriografija, siekiant nustatyti tradicijų tęstinumą arba pokyčius; taip pat tikrintos konkrečios nuotraukos Valstybinio Vilniaus Gaono žydų muziejaus (toliau VVGŽM) fonduose bei skaitmeniniuose internetu pasiekiamuose United States Holocaust Memorial Museum (toliau - USHMM), Yad Vashem, Ghetto Fighter's House ${ }^{7}$ ir kituose archyvuose.

Lietuvoje fotografijos, tiek istorinès, tiek meninès, tyrimais tradiciškai užsiima menotyrininkai. Jie linkę fotografijos istoriją pateikti remdamiesi konkretaus asmens kūryba, nagrinėdami tam tikrą meninę srovę ar

6 Turima omenyje prieiga prie leidinių Lietuvos bibliotekose (Vilniaus universiteto, Nacionalinejje Martyno Mažvydo ir Vilniaus žydų viešojoje) ar internetinejje erdvėje. Žinoma, viso pasaulio mastu vien su Holokaustu susijusių leidinių yra tūkstančiai, tad tyrimas yra neabejotinai ribotas.

7 Nuorodos ị internetinius puslapius atitinkamai: https://collections.ushmm.org/search/ http://collections1.yadvashem.org/search.asp?lang=ENG\&rsvr=7 http://infocenters.co.il/gfh/search. asp?lang $=\mathrm{ENG}$. 
organizaciją. Tačiau Holokausto fotografijai dažniausiai beprasmiška taikyti kokias nors kompozicinès analizės ar autorinės kūrybos kategorijas, taigi ji lieka už menotyrininkų akiračio. Tuo metu ị istorikų akiratị Holokausto tema, žinoma, patenka ir net nuolat skleidžiasi naujais straipsniais bei monografijomis, tačiau dèl vizualinio raštingumo stokos fotografijos šalinamasi kaip tyrimo objekto8.

Tiesa, panaši padètis šiuo klausimu susidariusi ir Vakaruose. Kaip teigia JAV istorikas Davidas Shneeras, nepaisant gausios Holokaustui ir Antrajam pasauliniam karui skirtos istoriografijos, istorikai iki šiol beveik nenagrinėjo Holokausto fotografijos, tad akademiniai šios srities tyrimai daugiausia priklauso komunikacijos ir kultūros teoretikams ${ }^{9}$

Pastarieji XX a. paskutiniame dešimtmetyje ir ypač pirmaisiais dviem XXI a. dešimtmečiais jau spėjo išvystyti atskirą kritinès Holokausto fotografijos studijų kryptị ir nubrěžti pagrindines problemines gaires. Vieni imasi gvildenti nevienareikšmius santykius tarp Holokausto kaip istorinès tikrovès, fotografinès jo reprezentacijos ir istorinès atminties ${ }^{10}$; kiti atlieka istorini tyrimą siekdami išsiaiškinti konkrečiu fotografinių atvaizdų atsiradimo aplinkybes ${ }^{11}$; treti ịvairiais būdais apjungia pirmąsias dvi kryptis kurdami pasakojimus, kuriuose išryškèja, kaip, kintant atminties politikai, keičiasi ir pirminès nuotraukų reikšmės ${ }^{12}$. Straipsnyje pristatomą tyrimą

8 Kaip išimtị galima paminèti Margaritos Matulytės, Agnès Narušytės knygą Camera obscura: Lietuvos fotografijos istorija 1839-1945 (Vilnius: Vilniaus dailès akademijos leidykla, 2016), kur karo fotografijai skirtame skyriuje šiek tiek aptartas fotografinis nacių okupacijos metu palikimas.

9 David Shneer, „Picturing Grief: Soviet Holocaust Photography at the Intersection of History and Memory“, in: American Historical Review, 2010, Nr. 1 (115), p. 28.

10 Mariene Hirsch, op. cit., p. 215-246; Susan A. Crane, op. cit., p. 309-330; Michael F. Bernard-Donals, op. cit.; Judith Keilbach, „Photographs, Symbolic Images, and the Holocaust: On the (im)possibility of depicting historical truth“, in: History and Theory, 2009, Nr. 2 (48), p. 54-76; Angi Buettner, Holocaust Images and Picturing Catastrophe: The Cultural Politics of Seeing, Farnham: Ashgate, 2011.

11 Judith Levin, Daniel Uziel, „Ordinary Men, Extraordinary Photos“, in: Yad Vashem Studies, 1998, Nr. 26, p. 280-293; Sybil Milton, „Photography as evidence of the Holocaust“, in: History of Photography, 1999, Nr. 4 (23), p. 303-312; David Shneer, Through Soviet Jewish Eyes: Photography, War and the Holocaust, New Brunswick, New Jersey: Rutgers University Press, 2010; Karel C. Berkhoff, „Total Annihilation of the Jewish Population: The Holocaust in the Soviet Media, 1941-45“, in: The Holocaust in the East: Local Perpetrators and Soviet Responses, sud. M. DavidFox, P. Holquist \& Martin, Pittsburg: University of Pittsburgh Press, 2014, p. 83-117; Judith Cohen, „Jewish Ghetto Photographers“, in: The Holocaust: Memories and History, sud. Victoria Khiterer et al., Cambridge: Cambridge Scholars Publishing, 2014, p. 86-105.

12 Barbie Zelizer, Remembering to Forget: Holocaust Memory Through the Camera's Eye, Chicago: University of Chicago Press, 1998; Janina Struk, op. cit.; David Shneer, Picturing Grief, p. 28-52. 
būtų galima priskirti pirmajai probleminei krypčiai, nes daugiausia dèmesio čia skirta fotografijoms, kaip reprezentuojančioms ir interpretuojančioms ivairius istorinius pasakojimus.

\section{Analitinès kategorijos - kas, iš kur, kada, kaip?}

Nepaisant XX a. stiprėjančios tendencijos su istorija visuomenę pažindinti vaizdais, jie vis dar nedažnai suvokiami kaip įrodymai, kurie turètų būti kruopščiai ištirti. Istoriniuose pasakojimuose neretai norima vaizdą pateikti tik kaip abstrakčią laiko ar temos iliustraciją ${ }^{13}$. Tačiau tokiu būdu iš nuotraukos „pavagiamas“ informacinis jos potencialas. Kaip teigia žydų studijų atstovas Michaelas Bernard-Donalsas - žiūrėdami ị atvaizdą, kuriame konkretaus įvykio savitumas sunaikintas, iš tikrujjų žiūrime tik ị tuščią kevalą ir manome, kad tai yra Holokaustas, vadinasi, formuojame nerišlią atmintį ${ }^{14}$.

Reikètų pradèti nuo pamatinio teiginio, kad Holokausto, kaip istorinio reiškinio apskritai, neįmanoma perteikti fotografija. Pagal šį klausimą nagrinėjusią medijų tyrëją Judith Keilbach, galima išskirti šias priežastis: a) pats Holokausto pobūdis - galutinis sprendimas - didele dalimi igyvendintas sistemine ìvairių politinių ir administracinių struktūrų veikla, o tokių organizacinių procedūrų ir struktūrų fotografija nepajēgi atvaizduoti; b) naikinimo mastas - nužudytujų skaičius toks milžiniškas, kad daugumos iš šešių milijonų aukų kūnų nebuvo įmanoma užfiksuoti fotojuostelèje, tad fotografija pajègi fizinị tragedijos mastą netiesiogiai ịvardyti nebent metonimijos būdu; c) Holokausto idejjos pagrindas - žydus sunaikinti nepaliekant menkiausio jų egzistavimo pėdsako.

Taip sunaikintų Europos žydų, savaime suprantama, nebuvo įmanoma nufotografuoti, nes nuotraukai reikalingas vaizduojamo objekto matomumas. Taigi paradoksaliai visi užfiksuoti Holokausto vaizdai perteikia neigyvendintą idèją, tai, kas išliko, nors turèjo būti sunaikinta ${ }^{15}$. Tad fotografija, jeigu apeliuojame ị protą, o ne į emocijas, gali ir turètų tarnauti tik kaip konkretaus ,ilaikinto“ ir ,ivietinto“ epizodo pažinimo šaltinis su aiškiais tiek prieš objektyvą atsidūrusiais, tiek už kadro ribų likusiais veikejjais, nes vien pagal apibrěžimą fotografija visada yra išimta iš konkretaus konteksto - sukūrimo, reprezentuojamos scenos ar vaizduojamo asmens gyvenimo.

13 Susan A. Crane, op. cit., p. 324.

14 Michael F. Bernard-Donals, op. cit., p. 79.

15 Judith Keilbach, op. cit., p. 60-61. 
Taigi nenuostabu, jog visi, kada nors kritiškai atsiliepę konkrečiai apie Holokausto ar apskritai apie fotografiją, pirmiausia pabrèžia nuotraukos konteksto svarbą jos suvokimui. Ši prielaida kyla iš epistemologinès paradigmos, kad nuotrauka yra ne tikrovès atspindys, o jos interpretacija, kurios prasmė atsiranda veikiant ịvairiems diskursams ${ }^{16}$. Kitaip tariant, nuotrauka yra materialaus aparato gaminys, įdarbintas konkrečiuose kontekstuose konkrečių jègų ir daugiau ar mažiau apibrèžtiems tikslams. Todèl, kaip rašo viena žymiausių Holokausto fotografijos tyrinètojų Janina Struck, „patikeję, kad nuotraukos atspindi praeities tikrovę, atsiduriame fikcijos karalystėje“"17. Istorikė Susan Crane žengia dar toliau ir primygtinai teigia: nors, dirbant su nuotraukomis, informacija gali būti apribota tik tuo, ką matome vaizde, kaip mokslininkai esame įsipareigoję ir privalome fotografijas kvestionuoti papildomai. Vizualiniai įrodymai, anot jos, istoriniame kontekste yra tik dar viena tyrimo šaltinių forma, tad istorikams privalu reaguoti ị etinị ịsipareigojimą išsiaiškinti apie nuotrauką viską, kas įmanoma, prieš ją panaudojant, perplatinant ar bandant pateikti kaip žmonijos ar istorijos pavyzdį ${ }^{18}$.

Yad Vashem fotoarchyvo tyrëjai Judith Levin ir Danielis Uzielis siūlo: kaip šaltinį naudojant Holokausto nuotraukas, būtina atsižvelgti ị fotografo ir nufotografuotujų tapatybes, nuotraukos sklaidos ir priklausymo vaizdų serijai aplinkybes, lydintị tekstą ir tai, kas pagal turimas žinias liko už kadro $^{19}$. USHMM istorikè Sybil Milton teigia, kad fotoaparatas nefiksuoja ìvykiu neutraliu ar laisvu nuo vertybinio vertinimo būdu, tad istorikas turi atkreipti dèmesị ị nuotraukos situaciją / aplinką, kilmę ir fotografo motyvus $^{20}$. J. Struck prideda: mūsų vaizduotè, informuota fotografijos konteksto, užpildo pasakojimą tuo, ko nematome, tuo, kas slypi už nuotraukos ribų ${ }^{21}$.

16 „Fotografinè reprezentacija atsiranda diskriminacinio techninio, kultūrinio ir istorinio proceso metu, kai tam tikri optiniai ir cheminiai prietaisai įdarbinami, idant susistemintų patirtị bei troškimus ir sukurtų naują tikrovę - popierinį atvaizdą, kuris per tolimesnius procesus gali tapti prasmingas ịvairiausiais būdais. Kiekvienoje proceso stadijoje atsitiktinis poveikis, tikslinga intervencija, pasirinkimai ir pokyčiai prisideda kuriant fotografijos prasmę. Taigi šitai nėra tik buvusios tikrovès moduliacija, o ir naujos savitos fotografijos tikrovès sukūrimas. Fotografija ịgauna prasmę tam tikrose transakcijose ir daro įtaką, bet negali rodyti ar būti rodoma priešfotografinei tikrovei kaip tiesa.“ John Tagg, The Burden of Representation: Essays on Photographies and Histories, Basingstoke: Palgrave Macmillan, 1988, p. 3.

17 Janina Struk, op. cit., p. 213.

18 Susan A. Crane, op. cit., p. 311.

19 Judith Levin, Daniel Uziel, op. cit., p. 281-282.

20 Sybil Milton, op. cit., p. 311.

21 Janina Struk, op. cit., p. 212. 
Taigi geriausiu atveju siūloma interpretuoti ir nuotraukai suteikti prasmę neužgožiant originalių jos sukūrimo aplinkybių, t. y. visiškai išnaudojant potencialą 22 .

Vienas svarbiausių kontekstinių žinių apie nuotrauką elementų fotografo, kurio pasaulèvaizdis neišvengiamai perteikiamas nuotrauka, tapatybė arba bent priklausomybė tam tikrai grupei. Pastebèta, kad viso pasaulio mastu viešojoje erdvejje dažniausiai vyrauja pačių nacių darytos Holokausto fotografijos, kurios pirmiausia funkcionavo kaip vokiečių viršenybès ir galios ịrodymas ${ }^{23}$. S. Crane primena: žiūrẻjimas į tokias nuotraukas atgaivina nusikaltèlio žvilgsnị ir žiūrètojo galvoje atkuria aukos nužmoginimą ir bauginimą ${ }^{24}$. Pavyzdžiui, nors dauguma nacių fotografų buvo profesionalai, ju geto nuotraukose žydų kančioms užuojautos nėra. Tuo metu žydų fotografai parodo daug aspektų, paslëptų nuo nacių, tad šios nuotraukos padeda geriau ịsivaizduoti gyvenimą gete ${ }^{25}$.

Vakariečių tyrimuose paprastai kalbama apie tris fotografų grupes - nacių, žydų ir amerikiečių išlaisvintojų. Lietuvoje šią schemą tenka koreguoti, amerikiečius pakeičiant sovietais ir ịtraukiant lietuvius kaip galimus pašalinius įvykių stebètojus. Toks teorinis suskirstymas vis dèlto kelia praktinių sunkumų, mat kai kurių epizodų nuotraukų autorius ne visada i̇manoma identifikuoti. Todėl nuspręsta prie sovietinių partizanų prisidejjusiu žydų nuotraukas traktuoti kaip sovietines, nes neaišku, ar fotografavosi patys žydai, ar specialiai tam reikalui iš SSRS atsiųsti fotožurnalistai ${ }^{26}$. $\mathrm{O}$ nacių okupacinės valdžios nuotraukas, kurias galejjo padaryti ir lietuvių fotografai, tačiau dirbę valdžios užsakymu, - naciams.

Kitas svarbus sandas - nuotraukos vaizduojamas įvykis, t. y. jos turinys. J. Struck visas Holokausto fotografijas pirmiausia grupuoja pagal temas (žiaurūs nusikaltimai, karo propaganda, getai, koncentracijos stovyklos, išlaisvinimas), o tada smulkiau tipologizuoja pagal autorius ir jų tikslus. J. Keilbach dèmesị sutelkia ị funkciją (mėgèjiški suvenyriniai kadrai,

22 Mark Moss, op. cit., p. 107.

23 Janina Struk, op. cit., p. 214; Judith Keilbach, op. cit., p. 63.

24 Susan A. Crane, op. cit., p. 311.

25 Victoria Khiterer, „Introduction“, in: The Holocaust: Memories and History, edited by Victoria Khiterer with Ryan Barrick, David Misal, Cambridge: Cambridge Scholars Publishing, 2014, p. xiv.

26 Kad gyvavo tokia praktika, teigia David Shneer, Trough Soviet Jewish Eyes, p. 94; Kad partizanus išvaduotame Vilniuje fotografavo garsus Pravdos fotokorespondentas Jakovas Riumkinas, atsimena Sara Ginaitè, Atminimo knyga, Vilnius: Margi raštai, 1999, p. 175. 
nacių vadovybei ir plačiajai visuomenei skirti vaizdai, amerikiečių fotožurnalistų užfiksuotos koncentracijos stovyklos ir pan. $)^{27}$.

Kadangi suskirstymą iš esmès lemia praktinè situacija, vaizdų blokas, su kuriuo dirbama, šiame tyrime pirmiausia buvo surinktos visos publikuotos nuotraukos ir, išnagrinėjus jų turini, išskirtos tokios loginės teminès grupès: žydų žudynių ir pažeminimo scenos; okupacinė vokiečių valdžia (tiek nacių pareigūnai, tiek vietinè administracija bei ịvairios policinès struktūros); gyvenimas getuose; antinacinis pasipriešinimas (prie sovietinių partizanų prisidejję žydai, antifašistinis pogrindis, taip pat miestų ,„švadavimo“ scenos), žydų palaikų ekshumacija (kaip kriminalinio tyrimo dalis); lietuviai baltaraiščiai, policinių ir apsaugos batalionų nariai (kadrai be vokiečių ir ne pogromų scenos); vietos (scenos be žmonių, tik kaip erdvinė nuoroda); karo griuvėsiai; lietuvių visuomenė (eiliniai gyventojai). Taip pat pažymèti, tačiau nesuskaičiuoti (nes niekad neaiškus nuotrauku padarymo laikas ir vieta, jos tarnauja kaip asmens redukcija) fotoportretai, kurių subjektai papildomai suskirstyti į žydu gelbètojus, lietuvius nacių aukas, antinacinio pasipriešinimo dalyvius, 16-osios lietuviškosios divizijos karius, eilinius žydus, nacių pareigūnus ir vermachto kareivius, lietuvius nacių kolaborantus. Toks suskirstymas leidžia pažvelgti ị skirtingus Holokausto veikejjų tipus ${ }^{28}$. Ypač daug diskusijų kyla dèl žudynes ir kitą žiaurų elgesį fiksuojančiu fotografiju publikavimo. Holokausto reprezentacijų tyrinètojai dažniausiai abejoja edukacine tokiu vaizdu verte, esą šios nuotraukos naciu sukurtos kaip pažeminimo aktas, ir mes jị tęsiame žiūrèdami29. Šalininkų argumentas dèl pareigos jausmo aukoms, idant niekad nepamirštume ju tragedijos ir visada būtume budrūs bei jautrūs mūsų esamuoju laiku galintiems vykti genocidams, atremiamas kontrargumentu, jog kuo labiau prisijaukiname žiaurumų vaizdus, tuo darosi silpnesnis mūsų moralinis bei etinis atsakas, kartu didejja tikimybè, kad nusikaltimai kartosis ${ }^{30}$.

Nuotraukos yra neatskiriama istorinio šaltinio dalis, o prasmę bei kontekstą suteikia tekstas. Būtent prierašas nukreipia tam tikra nuotraukos „perskaitymo“ linkme ir pasako, ką turètumėme matyti³1. Taigi nors

27 Judith Keilbach, op. cit., p. 63-67.

28 Tokia tipologija sukurta bandant išskirstyti visus publikacijose aptiktus fotoportretus ị prasmingas grupes.

29 Janina Struk, op. cit., p. 213-215.

30 Susan A. Crane, op. cit., p. 323.

31 Janina Struk, op. cit., p. 212 
fotografinis vaizdas žiūrovą paverčia liudytoju ir konstruoja kolektyvinę atmintị, tačiau būtent užrašas ir nuotraukos pamatymo kontekstas didžiaja dalimi lemia to liudijimo objektą ${ }^{32}$.

Publikacijose pateikti nuotrauku pavadinimai taip pat verti atidaus žvilgsnio. Jie šiame tyrime pagal pobūdị suskirstyti ị: a) informacinius (trumpas, apibūdinantis subjektą, vietą ir laiką); b) simbolinius (aprašytas ne konkretus vaizdas, bet abstraktinta, tarsi nuotrauka perteiktų bendresnị reiškini); c) ideologizuojančius (ryškus vertybinis vertinimas, implikuojami vaizde tiesiogiai nematomi dalykai); d) aiškinamuosius (be trumpos informacijos, pateikiamos ir vaizdo atsiradimo aplinkybės, aiškinamas vaizduojamas įvykis), e) personalinius (perteiktas asmeninis pasakotojo santykis su vaizdu, jam esant įvykių dalyviu ar pažįstant vaizduojamus asmenis, vietas).

Kontroversiškas simbolinis nuotraukų ịvardijimas - tarsi teigiama, kad vienas vaizdas gali perteikti Holokausto patirti bei prasmę, tačiau kritikai abejoja ir klausia, ar iš tikrujų galima suvokti visumą ar esmę ìvykio, kuris neretai apibūdinamas kaip esantis už ịprastinės reprezentacijos ribų ${ }^{33}$. Taigi grižžtame prie skyriaus pradžioje pristatytos idejjos. Vis dèlto i ši reikalą galima pažvelgti ir iš kitos pusès.

Anot J. Keilbach, simboliniai vaizdai gali būti apibūdinti ir teigiamai, kaip turintys galią sustiprinti jau egzistuojanti žinojimą. Kaip ir jokia nuotrauka jie negali perteikti visapusiško žinojimo apie Holokaustą, bet konkretus atvaizdas gali rodyti platesnį kontekstą metonimijos būdu. Sužadindami sąsajas ir iššaukdami esančius žinių archyvus, simboliniai vaizdai gali perduoti istorinę tiesą, nors ta tiesa nuotraukoje ir negali būti atvaizduota ${ }^{34}$. Vadinasi, populiarūs posakiai „Kiekviena nuotrauka pasakoja istoriją“ arba „Vienas vaizdas vertas tūkstančio žodžių“ - yra prasmingi tik tuomet, jei tas pasakojimas jau iš anksto įtvirtintas tekstiniu pavidalu ${ }^{35}$. Šiuos argumentus galima apibendrinti taip: nuotraukos simboliniais pavadinimais (pvz., Holokausto epizodas Lietuvoje) apeliuoja į kolektyvinę atmini ir sutvirtina jau žinomą naratyvą, tačiau neperteikia naujos informacijos ir iš esmès neprisideda prie istorinio tikrovès pažinimo.

Simbolizmas siejasi ir su kitu svarbiu šio tyrimo aspektu - ikoniškumu. Paprastai nuotrauka vadinama ikonine, kai apie ją kalbant daugeliui

32 Michael F. Bernard-Donals, op. cit., p. 58.

33 Barbie Zelizer, Introduction: On Visualizing the Holocaust, p. 2.

34 Judith Keilbach, op. cit., p. 68.

35 Janina Struk, op. cit., p. 212. 
žmonių nebereikalingas fizinis vaizdo buvimas, mat jis taip ịsirèžęs ị atmintị, kad be vargo atkuriamas vaizduotèje. Toki statusą fotografija gali igauti dèl kelių priežasčių - dažno kartojimo įvairiose medijose; gebejjimo sutalpinti kelias reikšmes, bendrines idejjas ir įsitikinimus; estetikos, sukuriančios paveikų intymios patirties pojūtit ${ }^{36}$. Sakykim, Holokausto atveju itin „mėgstami“ senolių, moterų ir vaikų atvaizdai kaip universaliai perteikiantys aukų pažeidžiamumą ir nekaltybę ${ }^{37}$. Todėl ypatingas dėmesys skiriamas ivairiuose leidiniuose pasikartojančioms nuotraukoms, analizuojant jų perteikiamas reikšmes ir ,ikoniškumo“ bruožus.

Kaip tirdama issitikino J. Struk, archyvai, saugantys Holokausto fotografijas, esti labai gausūs ir ịvairūs. Juose nuotraukos tvarkomos, registruojamos ir kategorizuojamos pagal biurokratines konvencijas. Archyvai (ar muziejų fondai) nèra neutralios erdvès: jie primeta savo prasmes fotografijoms. Būdai, kuriais jos tvarkomos, nulemti ne vien jų kilmės aplinkybių, bet ir archyvo steigejjų kultūros ${ }^{38}$. Dèl to sumanyta tiriant užfiksuoti publikacijų autorių santykị su nuotraukų šaltiniais - pažymėti, kiek ir kokiais archyvais (muziejų fondais ar kitomis publikacijomis) remtasi, kartu mėginta nustatyti santyki su archyvo tvarka. Čia iš karto galima paminèti, kad iš visų vartytų leidinių vienintelė Holokausto istorijos autorė Doris L. Bergen ìvadinejje knygos dalyje atkreipè dèmesi i i šio laikotarpio fotografijų naudojimo problemas ir kritiškai ịvertino savo iliustracijoms pasirinktas nuotraukas atskleisdama jų daugiasluoksniškumą ${ }^{39}$.

Galiausiai, remiantis empiriniais duomenimis, buvo parengtos dvi lyginamosios užsienio ir lietuviškos istoriografijos lentelès, kuriose prie kiekvieno leidinio pažymèta išleidimo data, autoriaus priklausomybè tam tikrai institucijai, iliustracijų šaltiniai. Iš pradžių užsimota patikrinti ir skirtingų metų tų pačių publikacijų leidimus, siekiant nustatyti, ar keitèsi nuotraukos ir jų pavadinimai, tačiau, nè viename leidinyje neaptikus jokių pasikeitimų, skiltis visai išimta iš bendros analizès lentelès. Kiekvieno leidinio nuotraukos išanalizuotos pažymint atitinkamomis sutartinėmis raidėmis jų turinị, fotografo perspektyvą, taip pat užfiksuotos geografinès vietos. Kadangi

36 Šios priežastys apibendrintos iš Judith Keilbach, op. cit., p. 69; Mark Moss, op. cit., p. 116; Aangi Buettner, op. cit., p. 4.

37 Janina Struk, op. cit., p. 211.

38 Ibid., p. 13.

39 Doris L. Bergen, War and Genocide: a Concise History of the Holocaust, 3rd ed., Lanham: Rowman \& Littlefield, 2016, p. 7-11. 
nuotraukos autorius ar jos padarymo vieta prieraše dažnai neįvardyta, ši informacija gauta tikrinant kituose leidiniuose bei archyvuose. Atskirai sudarytas ir visų leidiniuose paskelbtų fotografijų sąrašas, pažymint jų pasikartojamumą bei skirtingus prierašus.

\section{Rezultatai}

Pirmiausia, žvelgiant ị tyrimo šaltinių bloką, matyti, kad dauguma publikacijų išleistos per pastaruosius du dešimtmečius. Tokią situaciją lèmė kelios priežastys.

Lietuvoje pirmaisiais nepriklausomybès metais daugiausia dèmesio skirta istorinei sovietinès okupacijos patirčiai, tad dauguma šio tyrimo šaltinių išleista jau po 2000 m., išaugus susidomėjimui Holokausto tema.

Vakaruose, neskaitant išgyvenusių ir emigravusių žydų lokalių atsiminimų, likusių už tyrimo ribų, Holokausto Lietuvoje epizodai pateko i bendro pobūdžio istoriografiją taip pat tik po 1990-ujų, šio reiškinio naratyvams nuo koncentracijos stovyklų patirties išsiplètus iki buvusiose sovietinėse teritorijose vykusių masinių žudynių. Iki tol dèl Šaltojo karo metų politikos viešojoje erdvėje labiau nušviesta pokarinė nusikalstama sovietinio režimo veikla prieš Rytų Europos gyventojus ${ }^{40}$.

Be to, nors ir aptikti keli tyrimo kriterijus atitinkantys leidiniai, anglų kalba išleisti Izraelyje, juose nebuvo panaudota nė viena nuotrauka iš nacių okupacijos laikotarpio Lietuvoje. Vadinasi, galima teigti, kad istorinè fotografija intensyviai imta naudoti iliustruojant pasakojimus apie Holokaustą Lietuvoje tik per pastarąsias tris dekadas. Tai, žinoma, susiję ir su ivvade jau minèta išaugusia vizualikos įtaka visuomenei apskritai.

Pradèkime tyrimo rezultatų aptarimą nuo fotografijų šaltinių kategorijos. Daugiausia užsienyje leistų knygu rėmėsi Yad Vashem archyvu (8 iš 16), o Lietuvoje - VVGŽM (9 iš 20) arba LCVA (7 iš 20). Yad Vashem archyvo populiarumą galima sieti su tuo, kad prie daugumos knygų leidybos yra prisidèję šios institucijos darbuotojai. Nesunku įžvelgti aiškią tendenciją užsieniečiams nesinaudoti Lietuvos archyvais, o lietuviams - užsienio. Vieninteliame žydų gyvenimo Lietuvoje parodos kataloge ${ }^{41}$ remtasi USHMM,

40 David Shneer, Picturing Grief, p. 29-30.

41 Žydu gyvenimas Lietuvoje = Jewish life in Lithuania: Parodos katalogas, sud. Rūta Puišytè, Darius Staliūnas, Vilnius: Valstybinis Vilniaus Gaono žydų muziejus, 2001. 
Yad Vashem ir Beit Hatfutsot archyvais. Be to, penkiuose Lietuvos ${ }^{42}$ ir trijuose užsienio leidiniuose ${ }^{43}$ pastebèta ydinga praktika visai nenurodyti nuotraukų šaltinių, o kai kur jie paminèti knygos gale bendrai, neįvardijant, kurie konkrečiai vaizdai paimti iš kurio archyvo ar publikacijos ${ }^{44}$. Atskleidžiant paviršutinišką nuotraukų traktavimą verta pažymèti ir tai, kad nemažoje dalyje leidinių (5 Lietuvos ir 6 užsienio) pasinaudota tik vienu archyvu. Paskelbtų fotografijų pasiskirstymas pagal šaltinius pateiktas 1 diagramoje.

Pagal vaizdu geografiją galima sakyti, kad Holokausto Lietuvoje istorija yra pirmiausia Kauno istorija. Nuotraukų iš Kauno absoliuti dauguma tiek Lietuvos (19 iš 20, 59 proc. visų fotografijų), tiek užsienio (15 iš 16 ir 57 proc.) leidiniuose. Vilnius, be poros atsitiktinių vaizdų prie geto vartų ar okupacinės nacių valdžios karinių rikiuočių, atsiranda tik atëjus sovietams kaip išvaduotas ir sugriautas miestas, Panerius reprezentuoja visur tos pačios dvi fotografijos. Dar yra vienetiniai vaizdai iš Švenčionių, Zarasų, Pajuostès (miškas šalia Panevěžio), Joniškio, Leliūnų, o lietuviškuose leidiniuose prisideda ir Kèdainiai, Šiauliai, Utena, Jurbarkas, Marijampolè, Radviliškis. Jeigu visus vaizdus sudètume ant žemèlapio, jis atrodytų labai netolygiai ir blankiai - tankus Kaune (geto teritorija Vilijampoleje, VII ir XIX fortai, „Lietūkio“ garažas, gatvès ir oficialių renginių vaizdai), o kitose vietose po kelias ar tik po vieną nuotrauką, vakarų Lietuva liktų tik balta dėme.

Toki pasiskirstymą iš esmės lemia praktinis vaizdų prieinamumas. Vien internetu pasiekiamu Kauno geto vaizdų $u^{45}$ archyvuose yra keli šimtai. Taip pat kadangi Kaune buvo Lietuvos generalinès srities administracinis centras bei vermachto 16 -osios armijos štabas, mieste telkèsi daug nacių

42 Vladas Terleckas, The Tragic Pages of Lithuanian History (1940-1953), Vilnius: Petro ofsetas, 2014; Lietuvos istorija: Enciklopedinis iliustruotas leidinys, Vilnius: Mokslo ir enciklopediju leidybos centras, 2010; Lietuva, 1940-1990: okupuotos Lietuvos istorija, sud. Arvydas Anušauskas et al., Vilnius: LGGRTC, 2005; The Shoah (Holocaust) in Lithuania, sud. Joseph Levinson, Vilnius: Valstybinis Vilniaus Gaono žydų muziejus, 2007; Solomonas Atamukas, Žydai Lietuvoje XIVXX amžiais, Vilnius: Lituanus, 1990.

43 Karen Sutton, The Massacre of the Jews of Lithuania: Lithuanian Collaboration in the Final Solution, 1941-1944, Jerusalem: Gefen Publishing House, 2008; „The Good Old Days“: The Holocaust as Seen by Its Perpetrators and Bystanders, sud. Ernst Klee, Willi Dressen, Volker Riess, trans. Deborah Burnstone, foreword by Hugh R. Trevor-Roper, New York: The Free Press, 1991.

44 Pvz., Arūnas Bubnys, The Holocaust in Lithuania between 1941 and 1944, Vilnius: LGGRTC, 2011.

45 Cvi Hiršas Kadušinas (1910-1997), kalèdamas Kauno gete, padarė kelis šimtus nuotraukų ir išsaugojo negatyvus, kuriuos pasièmė 1945 m. emigruodamas ị Vakarus. Persikèlęs ị JAV, vardą ir pavardę pasikeitè ị George Kadish. Plačiau žr. George Kadish et al., Days of Remembrance, 198\%; Family Life in the Kovno Ghetto, San Francisco: Mellen Research University Press, 1991. 
pareigūnų ir kareivių ir jie paliko nemažai tiek oficialių, tiek mėgẻjiškai fiksuotų kadrų. Iš jokios kitos vietos Lietuvoje neturime nuoseklios nuotraukų kolekcijos. Vakarų Lietuva buvo ta vieta, kur Holokaustas prasidejo pirmiausia, ir žydai buvo greičiausiai nužudyti čia veikiant Tilžès gestapo operatyviniam būriui ${ }^{46}$, tad ši regioną galèjo užfiksuoti nebent vermachto propagandos kuopu fotografai ir tą padarè ${ }^{47}$, bet nuotraukos kol kas nepakliuvo ì publikacijų apie Holokaustą akiratị.

Užsienio leidiniuose temiškai daugiausia žudynių ir pažeminimo scenų net 13-oje iš 16 leidinių (iš viso 48 vaizdai), toliau - getų gyvenimas - 9-iuose iš 16 (27 vaizdai) ir antinacinis pasipriešinimas 6-iuose iš 16 (14 vaizdų). Kitų temų dalis nežymi [1 lentelė]. Žudynių ir pažeminimo scenų vyravimą, viena vertus, galima sieti su tuo, kad būtent tokia yra dalies nagrinètų leidinių tema, o kita vertus - su tuo, kad tokio pobūdžio nuotraukų kopijos, kaip nusikaltimo įrodymai, yra labiausiai paplitusios užsienio archyvuose. Negalima atmesti ir minties, kad Lietuva užsienio visuomenei tiek dèl sovietinės propagandos, tiek dèl Holokaustą išgyvenusių žydų pasakojimų paprastai regima kaip žydų žudikų kraštas, tad pagal šias nuostatas parenkami ir atitinkami vaizdai.

Lietuviškuose leidiniuose pirmaujanti tema - getų gyvenimas 18oje iš 20 leidinių (65 vaizdai), tada žudynių ir pažeminimo scenos 13-oje iš 20 (62 vaizdai). Palyginti su užsienietiškais, matyti portretų (11 iš 20$)$, griuvėsių (8 iš 20 ) ir vietų ( 8 iš 20 ) fotografijų gausa. Šią tendenciją nesunku susieti su sovietiniais leidiniais, kur taip pat galima pastebèti vyraujant ištisas fotoportretu galerijas (norint pabrèžti aukas, didvyrius ir niekšus) bei fizinius nuostolius implikuojančios nuotraukos (naciai kaip naikintojai, sovietai kaip atkūrèjai).

Apskritai sovietinėje istoriografijoje $\mathrm{e}^{48}$ nacių okupacijos laikotarpis dažniausiai pagrindžiamas vėlesnèmis fotografijomis - ekshumacijų,

46 Arūnas Bubnys, „Trumpa holokausto Lietuvoje istorija, istoriografija ir bibliografija“, in: Lietuvos gyventoju genocido ir rezistencijos tyrimu centras, [interaktyvus], http://genocid.lt/centras/ lt/891/a/, [žiūrèta 2020-08-28].

47 Pvz., karo metais spalvota degančios Tauragės fotografija įdèta propagandiniame vokiečių žurnale Signal, 1941, Nr. 16, p. 9.

48 Taikant tuos pačius kriterijus kaip ir pagrindiniams tyrimo šaltiniams, išnagrinėti šie leidiniai: Hitlerinè okupacija Lietuvoje, Vilnius: Valstybinė politinės ir mokslinės literatūros leidykla, 1961; Masinès žudynès Lietuvoje, d. I, sud. G. Erslavaitė, K. Rukšėnas, Vilnius: Valstybinė politinės ir mokslinès literatūros leidykla, 1965; Documents accuse, sud. B. Baranauskas, K. Rukšènas, Vilnius: Valstybinė politinès ir mokslinès literatūros leidykla, 1970; Masinès žudynès Lietuvoje, d. 2, sud. G. Erslavaitė, Vilnius: Valstybinè politinės ir mokslinės literatūros leidykla, 1973; Vytautas Žeimantas, Teisingumas reikalauja, Vilnius: Valstybinė politinės ir mokslinės literatūros leidykla, 1984. 
paminklų, memorialų ir lankytinų objektų vaizdais. Šios nuotraukos, žinoma, liko archyvuose ir buvo panaudotos jau nepriklausomos Lietuvos leidiniuose. Getu gyvenimo temos populiarumą lemia C. H. Kadušino fotografijų kiekis ir kokybè, jo nuotraukų kopiju gausu tiek Lietuvos, tiek užsienio archyvuose. Dar galima paminèti, kad užsienio leidiniuose nepublikuotas nė vienas žydus gelbėjusio lietuvio portretas, o Lietuvoje jie šiame žanre mėgstamiausi (7 leidiniuose iš 20 ).

Nors dèl žudynių ir pažeminimo scenų fotografijų gausos savaime vyrauja ir nacių perspektyva (Lietuvoje 37, užsienyje 29 proc. visų vaizdų), santykis tarp šios ir žydiškos gana harmoningas, palyginti su pasaulinėmis tendencijomis, kur paprastai vyrauja galios pozicijoje buvusių nacių sukurti vaizdai. Žydų darytų nuotraukų rasime beveik kiekvienoje lietuviškoje knygoje (18 iš 20 , iš viso 70 ) ir didesnẻje dalyje užsienio leidinių ( 9 iš 16 , iš viso 32). Tiesa, net 5-iuose užsienio leidiniuose visų paskelbtų Lietuvoje darytų nuotraukų autoriai - naciai, o vietiniuose leidiniuose tokių atvejų nėra. Nevengta nekvestionuotai naudotis ir sovietiniais vaizdais, jų yra 12-oje lietuviškų leidinių (iš viso 27) ir 8-iuose užsienio leidiniuose (iš viso 20).

Toks pasirinkimas neatsitiktinis - ekshumacijas, partizaninio pasipriešinimo dalyvius bei nacių sugriautus Lietuvos miestus fiksavo būtent sovietiniai fotografai. Lietuviško žiūros taško trūkumas susijęs su fizine tokio pobūdžio fotografijų stoka. Okupacinei valdžiai dirbusius lietuvius fotožurnalistus vertinant kaip nacių ideologijos skleidejus (nacių okupacijos laikotarpio spaudoje publikuotos Vytauto Augustino, Antano Naruševičiaus, Boriso Borjero ir kitų nuotraukos) nėra ar bent iki šiol viešai nežinoma esant nuotraukų serijos, atspindinčios su valdžia nesusijusio lietuvio žvilgsnị ì 1941-1944 m. laikotarpị. Ivvairiụ grupių, kurioms atstovauja fotografai, santykis pavaizduotas 2 diagramoje.

\section{Populiariausios, bet ne ikonos}

Lietuvos leidiniuose 59 proc. vaizdu paskelbti tik po kartą (nesikartoja nei sovietiniuose, nei užsienio), o užsienio atitinkamai 42 proc. Yra 211 skirtingų vaizdų (136 Lietuvos ir 75 užsienio leidiniuose). Taigi labai ryškių konkrečių atvaizdų vyravimo neaptikta, ir tai leidžia daryti išvadą, kad

$99-2020$

Acta Academiae Artium Vilnensis 


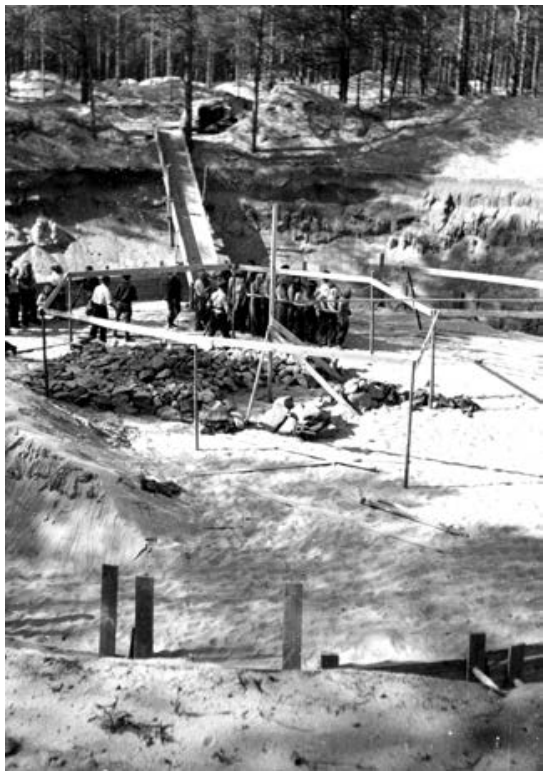

1.

Otto Schroff, Sovietų nebaigta statyti kuro saugyklos vieta Panerių miške, netoli Vilniaus, nacių okupacijos metais tapusi didžiausia masinių žudynių vieta Lietuvoje. Kairẻje - žydai verčiami kasti kanalą, juos saugo ginkluoti lietuviai. Dešinèje - žydai ị egzekucijos vietą vedami su ant galvos užmautais maišais. Fotografas - veiksmą iš viršaus stebejjęs 96-osios vermachto divizijos karininkas, $1941 \mathrm{~m}$. liepa, fotografija, Bundesarchiv

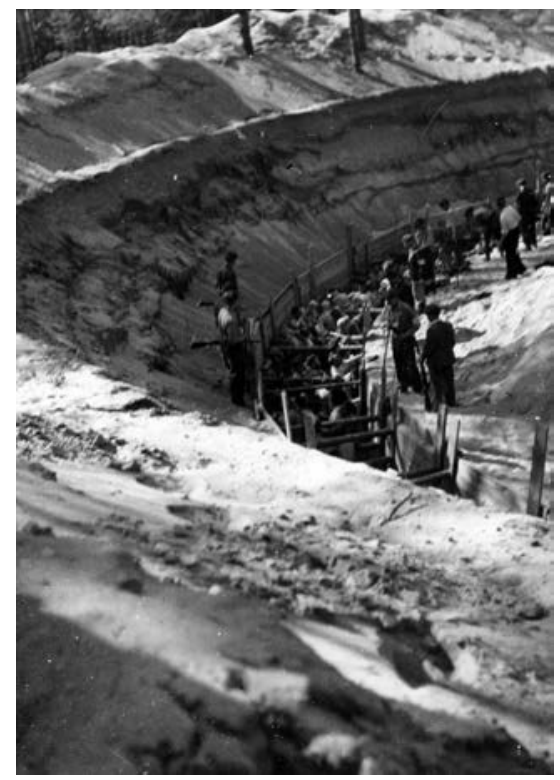

Otto Schroff, The site where the Soviet authorities started to build storage for petrol tanks in the Paneriai forest near Vilnius, in the years of the Nazi occupation became the largest mass annihilation site in Lithuania, July 1941

tvirtai susiformavusio lietuviško Holokausto vizualikos kanono nėra. Tačiau kelis populiaresnius vaizdus išskirti galima.

Pagal ịvykị pirmauja „Lietūkio“ garažo pogromo fotografijos - sudaro maždaug dešimtadalị visų vaizdų tiek užsienio, tiek Lietuvos leidiniuose. Tačiau, pažiūrèjus ị konkrečias, lyderiai išsiskiria. Užsienyje tą trejetuką sudaro nuotrauka iš Panerių [1 il.] (7 iš 16), apsuptos žydès Kaune (6 kartai, [2 il.]) ir „Lietūkis“ (5 kartai, [3 il.]). Nesunku pastebèti, kad čia gausiausiai pasikartojantys vaizdai - žydų žudynių ir pažeminimo scenos, kuriose veikia lietuvių baltaraiščiai.

Galimas tokių nuotrauku paklausos priežastis jau aptarėme. Lietuvos leidiniuose populiariausia nuotrauka - prie Kauno geto vartu 
surikiuotos žydų darbo brigados (7 kartai iš 20 leidinių [4 il.]). Po 5 kartus trys nuotraukos: grupinė žydų tarybos Kauno gete [6 il.]; žudynės Pajuostès miške prie Panevėžio [7 il.] ir kraustymasis i Kauno getą [5 il.]. Galima pastebèti, kad, išskyrus Pajuostę, vyrauja gana neutralūs Kauno geto vaizdai. Taip pat pirmaujantys vaizdai čia sudaro santykinai mažesnę dalį nei užsienio leidiniuose.

Šiek tiek anksčiau aptarėme, kad ịprastai ikoniniai vaizdai pasižymi savybe turèti kelias reikšmes ir perteikti universalias patirtis, tad priartèja prie didelio rato skirtingų žmonių. Pagal tokị apibrèžimą, daugumą ką tik paminètų populiariausių nuotraukų sunku pavadinti ikoninèmis. Pradèkime nuo Lietuvoje paplitusių trijų vaizdų iš Kauno geto. Atrodo, iš kelių šimtų specialiai pasirinktos pačios neutraliausios. Štai tolumoje matyti trys būreliai žmonių, lūkuriuojančių prie sargybos posto šalia geto vartų. Tai ir viskas, ką galima pasakyti apie šią nuotrauką. Dauguma figūrų nusisukusios, vien iš vaizdo neaišku, ko šie žmonès laukia, ne iš karto jॄžiūrimos ir prisegtos žvaigždès. Tik iš prierašų sužinome, kad tai iš darbo mieste i geto teritoriją gričžtančios darbo brigados.

Ką tokia nuotrauka sako apie Holokaustą Lietuvoje, kur didžiajai daliai žydų nebuvo suteikta proga nei dirbti, nei gyventi gete, kur pirmoji ir paskutinè kelionė buvo iki duobès krašto mirties link? Lygiai tą pati galima pasakyti ir apie kraustymosi ị getą nuotrauką: ją galima traktuoti nebent kaip Kauno žydų Holokausto istorijos pradžios simbolị.

Nedidelè ir sunkiai ịžiūrima penkių kabinete prie darbo stalo sèdinčių vyrų nuotrauka tarnauja tik kaip liudijimas, kad šie žmonės iš tikrųjų gyveno. Ir nors ji publikuota penkis kartus, tik dviejose Alfonso Eidinto knygose pasivarginta ịvardyti kiekvieną žmogų, jo einamas pareigas ir nuotraukos padarymo metus ${ }^{49}$. Kitais atvejais apsiribota prierašu Kauno geto seniūnų taryba. Tokį vaizdą sunku kaip nors interpretuoti, regime tik pastangą net ir tokiomis sąlygomis imituoti oficialų grupini portretą, siekị sukurti teisètos institucijos įvaizdị.

Pajuostès žudynių nuotrauka taip pat dviprasmiška. Svarbiausias vaizdo subjektas - ginkluotas vyras, nuspejjamas lietuvis iš policijos bataliono, o už jo nugaros - mirties laukiančios aukos. Viena vertus, lyg ir

49 Alfonsas Eidintas, Žydai, lietuviai ir Holokaustas, Vilnius: Vaga, 2002, il. 7; Lietuvos žydu žudyniu byla: dokumentu ir straipsniu rinkinys, sud. Alfonsas Eidintas, Vilnius: Vaga, 2001, il. 23 . 
pripažįstamas lietuvių dalyvavimas naikinant žydus, parodant konkretų nusikaltèlic. Tačiau jis taip ir lieka be vardo, o aukas regime tik kaip neryškias figūras kažkur fone, be to, iš nugaros. Tokią analogiją galima perkelti ir bendram istoriniam Holokausto Lietuvoje naratyvui - pripažistame, bet tiksliai neįvardijame, nesiekiame suprasti konkrečiu ịvykių aplinkybių. Apskritai, panašu, kad šie dažni vaizdai tokiais tapo veikiau iš inercijos, per daug neapmąstant jų funkcijos, o perspausdinant lengviausiai prieinamas nuotraukas.

Paneriu nuotraukų porą galima pavadinti ,ikonomis per prievartą“, nes $1941 \mathrm{~m}$. liepą 96-ojo pėstininkų pulko kareivio Otto Schroffo užfiksuoti kadrai yra vieninteliai žinomi vaizdiniai šio laikotarpio liudijimai ${ }^{50}, o$ poreikis iliustruoti didžiausią ir daugiausia auku pareikalavusią žudynių vietą Lietuvoje milžiniškas. Tačiau šios fotografijos savaime sunkiai perprantamos - matome milžiniškoje pušyno dauboje neaiškią medinę struktūrą, dalị vaikštinëjančių, dalị stovinčių vyrų ir, tik priartinus žvilgsnį, paaiškẻja, kad stovintiesiems ant galvų užmaukšlinti medžiaginiai maišai (kai kur kadruota būtent ši nuotraukos dalis), gretimoje irgi sunku suprasti, kad matome masinių žudynių vietą, o ne paprastus priverstinius darbus - vyrai kasa žiedo formos kanalą, sutvirtintą mediniu karkasu, o juos stebi ginkluoti sargybiniai. Dėl didelio atstumo tarp fotografo ir jo subjektu sunku ižziūrèti kokią nors emociją, žvilgsnis tik neutraliai skenuoja paskiras nuotraukos detales. Todèl dalyje leidinių prie šių vaizdụ poros vietoj Masinès žudynès Paneriuose, $1941 \mathrm{~m}$. pateiktas išsamesnis paaiškinimas: maišais uždengti žydai čia atvesti sušaudyti, o duobė buvo dar nuo sovietu laikų. Kitaip atsitiktiniam skaitytojui be pašalinio žinojimo būtų sunku suprasti, ką iš tikrujų mato.

Priešingai nei Paneriu atvejis, kai vieta ir su ja susiję įvykiai vieninteles jų nuotraukas pavertè ikoninèmis, „Lietūkio“ garažo ịvykiai plačiai pasklido tik 6-ojo dešimtmečio pabaigoje, Vokietijos teisèsaugininkams aptikus inkriminuojančias nuotraukas. Šiandien, kaip konstatavo Gražina Sviderskytė, „Lietūkio“ garažo byla neretai laikoma Lietuvoje vykdyto

50 Galima aptikti ir dar porą neaiškios kilmès ir žemos kokybės nuotraukų, kai kur priskiriamų tam pačiam O. Schroffui, nors jis savo liudijime mini tik du kadrus, žr. „Ponary, Poland, Jews who were led to the place they will be executed by Lithuanian militiamen“, 1941, in: Yad Vashem, [interaktyvus], http://collections1.yadvashem.org/notebook_ext. asp?item =100107\&site= sapir\&lang =ENG\&menu=1, [žiūrèta 2020-08-28]; ,Ponary, Poland. Two Jews just before their execution, surrounded by German soldiers, June-July 1941“, in: Yad Vashem, [interaktyvus], http://collections1.yadvashem.org/notebook_ext.

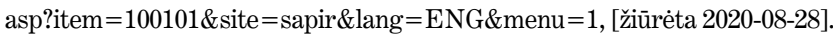


Holokausto simboliu ${ }^{51}$. Tačiau iš devyniolikos žinomų Kaune birželio $27 \mathrm{~d}$. vykusių ir ịvairių fotografụ padarytų žudynių nuotraukų leidiniuose aptikta tik dešimt, iš jų dauguma ịdèta vieną kartą. Tad vokiečių puskarininkio Karlo Röderio užfiksuoto vaizdo paklausos reikia ieškoti kitur.

Kuo gi jis ypatingas? Fotografijos teorijoje gyvuoja terminas decisive moment - elementas, darantis ypatingą poveiki žiūrovui ${ }^{52}$. Jis nuotraukoje atsiranda tada, kai pavyksta užfiksuoti lemiamą akimirką, veiksmą prieš pat kažkam nutinkant. Henri Cartier-Bresonas paliko per balą šokantị praeivit ${ }^{53}$, Anatolijus Garaninas skeveldros ką tik pakirstą kareivị ${ }^{54}$, o K. Röderis - lazda prieš gulinčią auką užsimojusị lietuviu ,aktyvistą“. Tokios nuotraukos dažniausiai perauga vien ịvykio fotodokumento statusą ir veikia jau emociniame lygmenyje.

Dar viena ikoninių savybių turinti nuotrauka - Kaune nenustatyto autoriaus ir tiksliai neidentifikuotu metu užfiksuotas kadras, kurio kairèje - gatve einantis būrys moterų, o dešinėje - grupė ginkluotų vyrų su trispalviais raiščiais ant rankų [2 il.]. Čia pirmiausia aiški fizinė atskirtis tarp dviejų grupių, kadro vidurị kertanti tuštuma. Taip pat kontrastuoja išvaizda: lengvomis vasarinėmis suknelėmis vilkinčios žydės ir ginkluoti „namudines“ uniformas vilkintys lietuviai. Galiausiai nevienodus galios santykius išduoda žvilgsniai - visos priekyje esančios moterys žengia, akis nudelbusios ị žemę, ir tik kelios gale nedrąsiai žvelgia ị objektyvą, o vyrų grupė jas atidžiai stebi. Tokia nuotrauka daugumos žmonių vaizduotejje virsta universaliu nekaltos, apsiginti negalinčios aukos ir agresoriaus be jokių skrupulu akistatos simboliu.

Ieškant tęstinumo, vos penki vaizdai pasikartoja ir sovietiniuose, ir užsienio, ir nepriklausomos Lietuvos leidiniuose. Tai žudynių Pajuostės miške; Zarasų baltaraiščių rikiuotėje; IX forto pastato; nacių vadų ir apskričiu viršininkų susitikimo Kaune; Rokiškio žydų žudynių (fotografijos autentiškumą dar aptarsime) nuotraukos. Be sovietmečio, nuotraukų, pasikartojusių bent viename Lietuvos ir užsienio leidinyje, rasta 33, taigi vietiniai ir užsienio knygų sudarytojai akivaizdžiai linkę rinktis skirtingus vaizdus, ir tai būtų logiška sieti su aptarta nevienoda archyvinių šaltinių pasiūla.

51 Arvydas Anušauskas, Gražina Sviderskytè, XX amžiaus slaptieji archyvai. Dvylika istorijos detektyvu, Vilnius: Versus aureus, 2008, p. 61.

52 Termino autorius ir propaguotojas H. Cartier-Bressonas.

53 Henri Cartier-Bresson, Place de l'Europe, Paris, fotografija, 1932.

54 Анатолий Гаранин, Смерть солдата, Ржев, fotografija, 1942. 


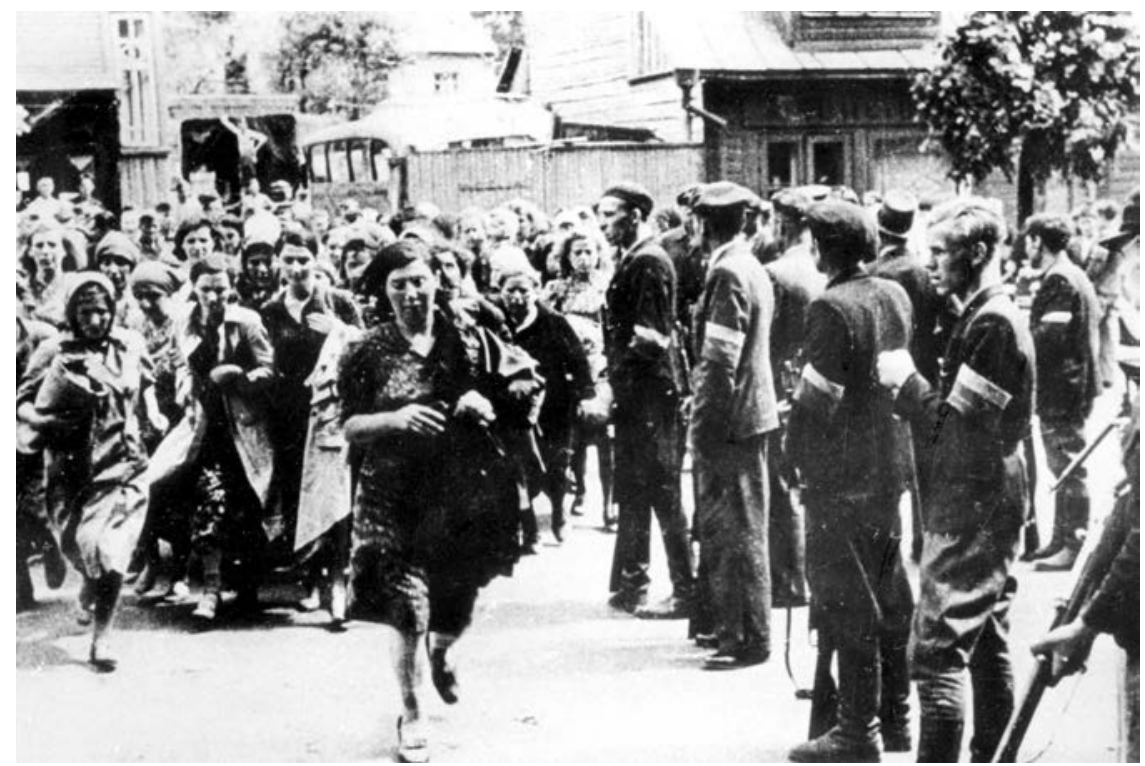

2.

Nežinomas fotografas, Suimtos ir lietuvių savisaugos dalinių narių vedamos žydų moterys Kaune, 1941, fotografija, Yad Vashem archyvas
Unknown photographer, Arrested Jewish women led by members of the Lithuanian self-defence units in Kaunas, 1941

\section{Prierašai}

Prie nuotraukų pateikti prierašai tiek lietuviškuose, tiek užsienio leidiniuose dažniausiai yra informacinio pobūdžio - identifikuotas ịvykis, vieta, laikas. Lietuviškuose leidiniuose, jeigu tai ne fotoportretai, pastebimai vengiama ịvardyti konkrečius asmenis, nors tokia informacija ir būna pasiekiama (14-oje nuotraukų būtų galima identifikuoti bent vieną iš 191). Tiksliu ịvardijimu nepasižymi ir užsienio leidiniai (19 fotografijų iš 115), tačiau dažniausiai vardai suteikiami antinacinio pasipriešinimo dalyviams, kur kaip ryškiausia figūra pabrèžiamas vilnietis partizanas Aba Kovneris. Aptikti vos keli atvejai, kai aiškintos konkrečios nuotraukos atsiradimo aplinkybès ar atkreipiamas dèmesys i autorių.

Nors tarp tirtos literatūros autorių buvo ir ịvykių dalyvių bei liudytoju - Aba Gefenas, Yitzhakas Aradas, Alexas Faitelsonas, Dovas Levinas, Solomonas Atamukas, Josifas Levinsonas - vienintelis A. Faitelsonas 
nuotraukas komentavo, pavyzdžiui, Lietuviu partizanu sučiupti žydai Kauno prieigose vedami i sunaikinima. Tarp ju mano pusbrolis Faivlas Aharonovičius ir jo žmona Lèja (pažymèti X), $1941 \mathrm{~m}{ }^{55}$ arba Namas Linkuvos ir Dvaro gatviu kampe, kur mano šeima gyveno nuo $1938 \mathrm{~m}$. Skaičiais pažymèti romantiški laipteliai, autorius ir Moišè Segelsonas ${ }^{56}$. Tokia prieiga priartina užfiksuotą ìvykị prie žiūrètojo, leidžia giliau issijausti, skatina ilgesnius apmąstymus, įdėmesnį žvilgsnị į nuotrauką. A. Faitelsono namo fotografija yra ir kituose leidiniuose, tačiau, neįvardijus nei asmenų, nei fotografo (C. H. Kadušinas), pavadinta, sakykim, Gatvès kampas Kauno gete ${ }^{57}$.

Iš prierašu galima pamatyti, ir kaip skirtingai pateikiami tie patys ìvykiai, tarkim, lietuviškuose leidiniuose dažna nuotrauka iš prie Panevėžio vykusių žydų žudynių. Jos pavadinimai tokie: Žydu žudynès netoli Panevé$\check{z} i o^{58}$ (akcentas - žydai kaip aukos, bet nèra kaltininku); Žydu žudynès netoli Panevėžio. 1941 m. nuotrauka. Pirmame plane-egzekucijos vieta saugantys lietuviu policijos bataliono kariai ${ }^{59}$ (aiškiai ịvardijama, kas tie lietuviai, bet jie - ne žudynių vykdytojai). Viename užsienio leidinyje po nuotrauka prierašas - Lietuviu „aktyvistai“ žudo Panevėžio žydus ${ }^{60}$ (akcentas - tik lietuviai kaip budeliai). Ši nuotrauka pasirodè ir sovietinejje istoriografijoje, kur pavadinimas Lietuviškieji buržuaziniai nacionalistai talkininkauja žudant žydus Panevėžyje $e^{61}$ taip pat ìvardija lietuvius kaip kaltininkus, bet pažymi ir tai, kad jie nèra pagrindiniai organizatoriai. Čia įdomu ir tai, kad aukomis aiškiai įvardijami žydai, o ne tarybiniai piliečiai, kaip buvo būdinga to laikotarpio retorikai.

Kitas pavyzdys - kai pagal vaizdą nepagrịstai kuriama situacija. Turime jau aptartą nuotrauką, kurioje matyti lietuvių apsuptos žydės Kaune. Pagal vasarinius drabužius ir gana puošnią moterų išvaizdą galima spèti, kad tai nacių okupacijos pradžia - $1941 \mathrm{~m}$. birželio pabaiga, liepa ar rugpjūtis. Tačiau daugiau tikslios informacijos apie nuotrauką nèra. Vis dèlto skirtinguose leidiniuose teigiama, kad čia: a) lietuvių kolaborantai veda

55 Alex Faitelson, Heroism \& Bravery in Lithuania 1941-1945, Jerusalem: Gefen Publishing House, 1996, p. 21.

56 Ibid., p. 106.

57 Michael Berenbaum, The world must know: the history of the Holocaust as told in the United States Holocaust Memorial Museum, Boston: Little \& Brown, 1993, p. 86.

58 Lietuva, 1940-1990: okupuotos Lietuvos istorija, p. 211; Arūnas Bubnys, The Holocaust in Lithuania between 1941 and 1944, p. 13.

59 Ignas Kapleris et al., XX a. Lietuvos ir pasaulio istorija, Vilnius: Briedis, 2009, p. 173.

60 Alex Faitelson, op. cit., p. 42.

61 Hitlerinè okupacija Lietuvoje, p. 83. 
žydus ị egzekucijos vietą ${ }^{62}$; b) partizanai lydi žydus ị Kauno getą ${ }^{63}$; c) lietuvių policija saugo ką tik ị Kauną iš provincijos atvežtus areštuotus žydus ${ }^{64}$; d) nusikaltèliai lietuviai varinėja žydus Kauno gatvėmis ${ }^{65}$. Visos šios istorijos kartu negali būti teisingos, tad peršasi mintis, kad nuotraukos parašus nulèmé autorių ar leidèjų vaizduotè, o ne istorinè tikrovè.

Dar vaizdingesni aprašymai lydi nuotraukas iš „Lietūkio“ garažo žudynių. Čia aktyviausi užsienio autoriai, pasakodami apie žiaurius lietuvių vykdytus žydų kankinimus, kraujo ištroškusius žiūrovus ir fotografuojančius vokiečius ${ }^{66}$. O lietuviškuose leidiniuose pažymèta tik data, vieta ir tai, jog matome žydu žudynes ${ }^{67}$. Vienintelejje publikacijoje pripažistama, kad „daugelis žudynių aplinkybių iki šiol neišaiškintos, neatpažinta didžioji dalis dalyviu, lieka paslaptis ir tikrasis aukų skaičius" ${ }^{\text {"68, }}$, taip pat tik viename leidinyje remtasi naujausiais A. Anušausko ir G. Sviderskytès argumentais, kad pogromą inicijavo vokiečiai ${ }^{69}$.

\section{H. Kadušinas - pamirštas populiariausių nuotraukų autorius}

Kaip paaiškejjo analizuojant tyrimo rezultatus, svarbią vietą fotografiškai reprezentuojant Holokaustą Lietuvoje užima C. H. Kadušino nuotraukos iš Kauno geto. Užsienio leidiniuose jos sudaro 22,5 proc. visų vaizdų, lietuviškuose 32,5 proc. Bent vieną C. H. Kadušino fotografiją rasime kiekviename leidinyje. Būtent šio fotografo palikimas lëmẻ tiek Kauno vaizdų, tiek geto gyvenimo temos, tiek žydiškos perspektyvos įsitvirtinimą knygose apie Holokaustą. Tai, kad i i ši laikotarpi galime pažvelgti žydo akimis, yra gana unikalu pasauliniame kontekste, kur tokie atvejai vienetiniai ${ }^{70}$.

62 The Pictorial History of the Holocaust, sud. Yitzhak Arad, Jerusalem: Yad Vashem, 1990, p. 169; The Encyclopedia of Jewish Life Before and During the Holocaust, sud. Shmuel Spector, Geoffrey Wigoder, New York: New York University Press, 2001, p. 1540.

63 Karen Sutton, op. cit., p. 48.

64 Alfonsas Eidintas, Žydai, lietuviai ir Holokaustas, il. 28.

65 „The Good Old Days“, p. 25.

66 Ibid., p. 26, 30; Alex Faitelson, op. cit., p. 24; Daniel Jonah Goldhagen, Hitler's Willing Executioners: Ordinary Germans and the Holocaust, New York: Random house, 1997, p. 151; Dov Levin, The Litvaks: A short History of the Jews in Lithuania, Jerusalem: Yad Vashem, 2000, p. 217.

67 Arūnas Bubnys, Vokiečiu okupuota Lietuva (1941-1944), Vilnius: LGGRTC, 1998, il. 15; Alfonsas Eidintas, Žydai, lietuviai ir holokaustas, p. 29; Lietuva, 1940-1990: okupuotos Lietuvos istorija, p. 202; Solomonas Atamukas, Lietuvos žydu kelias: nuo XIV a. iki XXI a. pradžios, Vilnius: Alma littera, 2001, p. 248; Rūta Vanagaitè, Mūsiškiai, Vilnius: Alma littera, 2016, p. 37.

68 Ignas Kapleris et al., op. cit., p. 169.

$69 \check{Z}$ ydu gyvenimas Lietuvoje = Jewish life in Lithuania, p. 161.

70 Vienintelis žinomas analogas - Mendelio Grossmano ir Henryko Rosso Lodzès geto fotografijos. Plačiau žr. Andrea Löw, „Documenting as a ,Passion and Obsession‘: Photographs from the Lodz (Litzmannstadt) Ghetto“, in: Central European History, t. 48, Nr. 3, 2015, p. 387-404, [interaktyvus], https://doi.org/10.1017/S0008938915000801, [žiūrèta 2020-08-28]. 


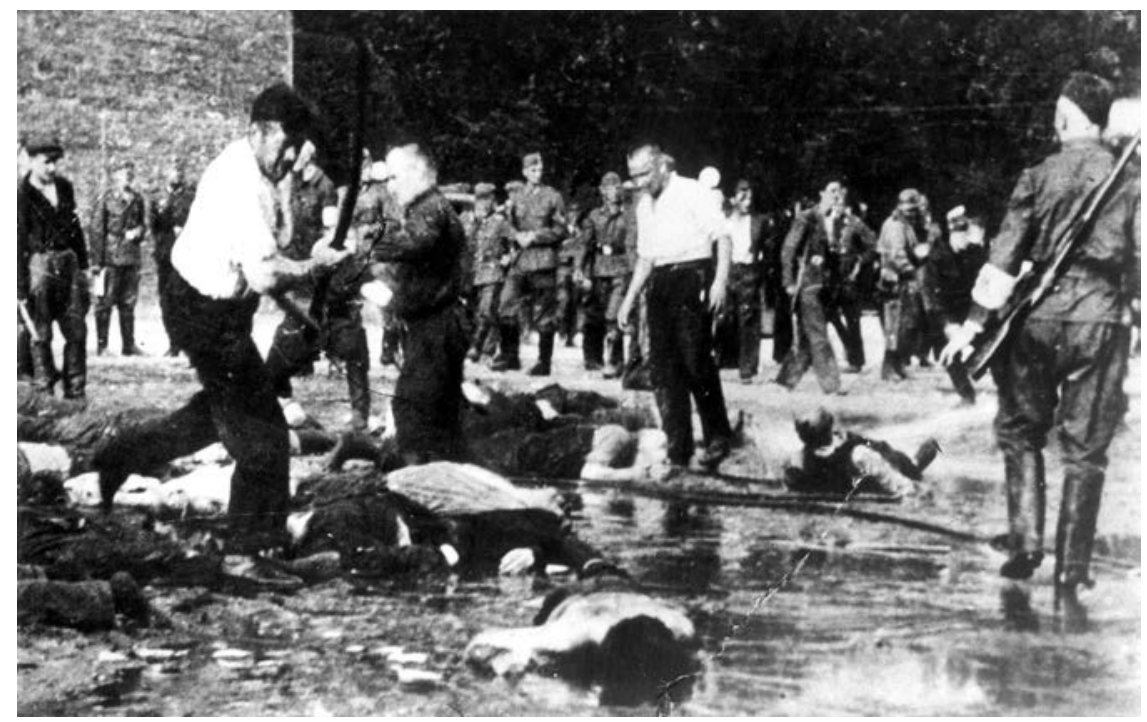

3.

Karl Röder, Viena iš iki šiol prieštaringai vertinamo pogromo, vykusio nacių okupacijos pradžioje Kaune, „Lietūkio“ garažo kieme (šalia Žalgirio gatvès ir Vytauto prospekto, priešais Kauno kapines) nuotraukų. Manoma, kad žudynes, kai mirtinai sumušti apie 50 žydų, inicijavo vokiečiai, o vykdè lietuviai. Užfiksuotas pogromo epizodas, vykęs iki susirenkant pašalinių stebètojų miniai. Fotografas pro šalį važiuojantis 16-osios vermachto armijos tiekimo komandos puskarininkis. Ši ir dar viena to paties autoriaus nuotrauka viešai pirmą kartą publikuota $1958 \mathrm{~m}$. VFR laikraštyje, $1941 \mathrm{~m}$. birželio 27 d., fotografija, Yad Vashem archyvas
Karl Röder, Photograph of the pogrom at the Lietūkis garage in Kaunas, 27 June 1941

Tačiau kol užsienyje rengiamos G. Kadishui skirtos parodos ir leidžiamos knygos ${ }^{71}$, Lietuvoje vis dar aiškiai neįvertinta išskirtinè net ir pasauliniame kontekste šių nuotraukų atsiradimo istorija, C. H. Kadušino gyvenimas. Pastraipa jam skirta Lietuvos fotografijos istorijoje ${ }^{72}$, tačiau tendencija tokia, kad lietuviškuose leidiniuose gausiai naudojamos fotografo nuotraukos nenurodant autoriaus. Atsakomybė iš dalies tenka archyvams, kur nuotraukos vis dar neidentifikuotos, nors, pasikalbejjus su darbuotojomis, paaiškejjo: autorių jos žinojo ir nustebo, kad jis neįrašytas atitinkamų fotografijų pavadinimuose ir aprašymuose ${ }^{73}$.

71 Pvz., George Kadish et al., Days of Remembrance, 198\%: Family Life in the Kovno Ghetto. 72 Margarita Matulytè, Agnè Narušytè, op. cit., p. 563-564.

73 C. H. Kadušino nuotraukų kopijų turi VVGŽM ir LCVA Fotodokumentų skyrius. 
1945 m. C. H. Kadušinui emigravus į Vokietiją, o netrukus į JAV, sovietiniai Lietuvos archyvai, turintys 1944-1949 m. veikusio Žydų muziejaus ${ }^{74}$ ir kitais nenustatytais būdais likusių jo nuotraukų, dèl suprantamų priežasčių iš jų turèjo pašalinti informaciją apie nepageidaujamą autorių, idant būtų galima jas panaudoti. Ir nors C. H. Kadušino nuotraukų neaptiksime bendro pobūdžio sovietiniuose leidiniuose apie nacių okupacijos laikotarpi Lietuvoje, tačiau jų pasirodè nagrinèjant siauresnes temas ${ }^{75}$. Lietuvai atgavus nepriklausomybę, šie svarbūs fotodokumentai inertiškai perimti su senaisiais aprašymais. Tokiu būdu unikalios ir išskirtinès žydų fotografo nuotraukos ir dabar pateikiamos kaip savaime suprantamos, tarsi nukritusios iš oro.

Štai Vilniaus getas savojo fotometraštininko neturèjo, tad šiandien ji reprezentuoja tik keli vokiečių vaizdai ties geto vartais, siužetai iš spektaklių ir sovietinės nuotraukos, padarytos iškart po miesto „išvadavimo“. Tuo metu C. H. Kadušino dèka galime pamatyti vidini Kauno geto gyvenimą - užeiti ị slaptą mokyklą ar dirbtuves, laukti eilèje prie maisto ar vaistų, gatvėje sutikti slaptus prekeivius ar pogrindžio narius, stebėti deportacijas, kasdienę darbo brigadų kelionę ar bulvių sodinimą. Kaip teigia Efroimo Oshrio memuarų ižangos autorius Chaimas Liebermanas - Kauno geto nuotraukos yra itin svarbios, mat žydą matančiam kaip bjaurastị ir gyvuli bei pasauliui tokị perteikusiam nacių žvilgsniui suteikia atsvarą ${ }^{76}$. Kitaip tariant, galime pažinti žydus kaip gyvenančius žmones, o ne kaip beasmenes aukas. Ši C. H. Kadušino nuotraukų savybè neabejotinai ir lemia jų populiarumą.

\section{Autentiškumo klausimas}

Tiriant buvo išsiaiškinta, kad devyniuose leidiniuose išspausdintos nuotraukos klaidingai arba nepagristai identifikuojamos su Lietuva.

Net keturios, kurių klaidingą tapatinimą galima nesunkiai ịrodyti, paskelbtos minètoje buvusio Kauno geto ir IX forto kalinio A. Faitelsono knygoje Heroism \& Bravery in Lithuania 1941-1945. Viename išblukusiame vaizde matome tris nuogus vyrus ir už jų stovinčius tris kareivius bei du civilius vyriškius su ginklais ${ }^{77}$. Autorius rašo, kad tai masinès egzekucijos scena iš Lietuvos, o vienas civilis netgi pažymètas žvaigždute kaip kunigas.

74 Tą liudija Žydų muziejaus antspaudai ant nuotraukų iš VVGŽM fondų.

75 Pvz.: M. Eglinis, Dmitrijus Gelpernas, Kauno getas ir jo kovotojai, Vilnius: Mintis, 1969.

76 Chaim Lieberman, „Foreword“, in: Efroim Oshry, Hurbm Lite, Nyu York: aroysgegebn fun ha-Rav E. Oshri bukh komitet, 1951, p. 467.

77 Alex Faitelson, op. cit., p. 43. 


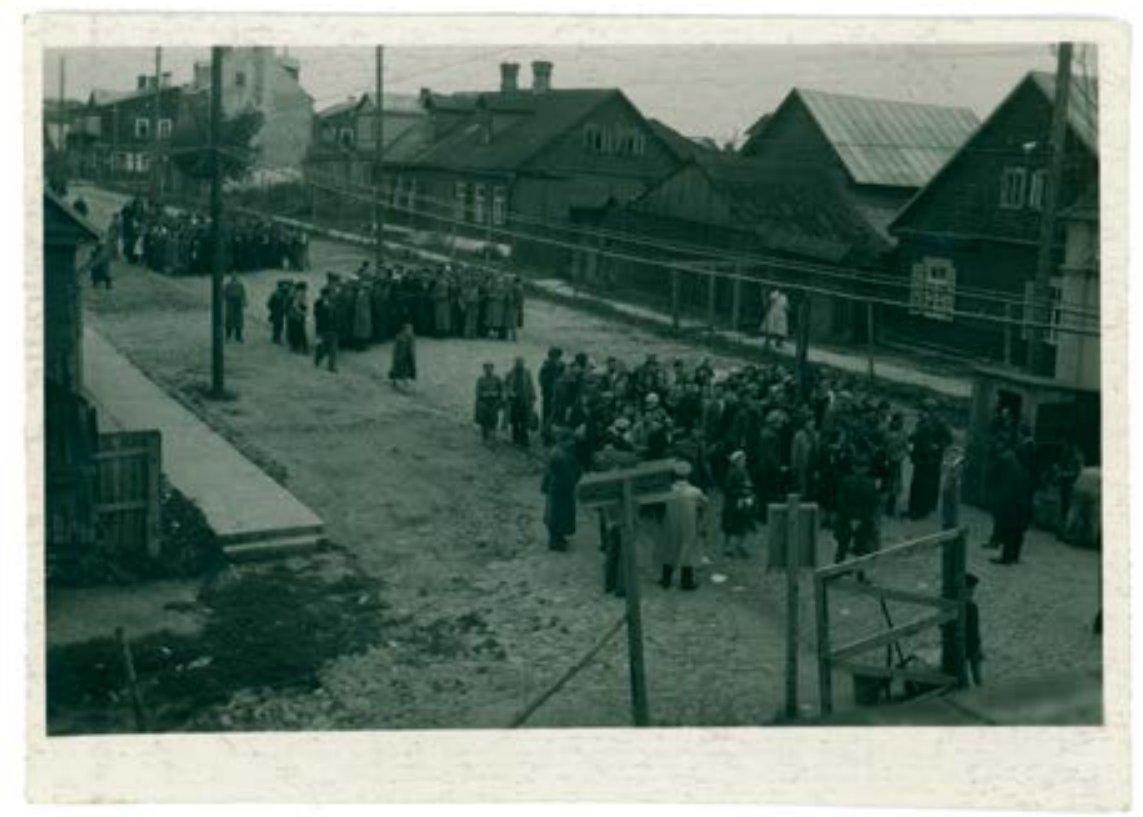

4.

[Cvi Hiršas Kadušinas], Iš miesto grižtančios Kauno geto darbo brigados laukia patikrinimo prie vartų. Tikrinimus, kai buvo ieškoma uždraustų i geto teritoriją issinešti maisto produktų ir kitų vertingu daiktų, atlikdavo žydų policininkai, lietuviai arba vokiečiai sargybiniai, [1941-1944], fotografija, LCVA
[Zvi Hirsh Kadushin], Work brigades of the Kaunas ghetto returning from the city at the check-up point at the gate, [1941-1944]

Tačiau nesunku pastebèti, kad pažymètasis - ne kunigas, mat vilki ne sutaną, o ilgą paltą, baltus marškinius su kaklaraiščiu ir skrybèlę. Čia nurodytas ir šaltinis - Paryžiuje esantis Šiuolaikinis žydų dokumentacijos centras (The Centre de documentation Juive Contemporaine), tačiau skaitmeniniame jo fotoarchyve ${ }^{78}$ prie šios nuotraukos reikšminių žodžių Lietuvos nèra.

Lygiai tokiu pačiu pavadinimu ši nuotrauka pasirodè ir USHMM leidinyje ${ }^{79}$. Tikrąsias vaizdo, dažnai aptinkamo Holokausto naratyvuose skirtingais pavadinimais, atsiradimo aplinkybes smulkiai išnagrinèjo J. Struk ir, Lenkijos archyve radusi originalų negatyvą su užrašu, nustatė, kad fotografija daryta 19430511 Sniatine (buv. Lenkija, dab. Ukraina) ${ }^{80}$.

78 The Phototheque, [interaktyvus], http://www.memorialdelashoah.org/en/archives-anddocumentation/the-documentation-center/the-phototheque.html, [žiūrèta 2020-08-28].

79 Michael Berenbaum, op. cit., p. 114.

80 Janina Struk, op. cit., p. 3-7. 
Antra nuotrauka, pavadinta Išlaisvintojai veda moteris ir vaikus i mirti, vaizduoja žiaurią sceną, kur baltaraiščio pašonėje matyti eilè nuogu moteru su kūdikiais ant rankų ${ }^{81}$. A. Faitelsonas šaltinio nenurodo, tačiau sisteminga paieška archyvuose atskleidžia, kad tai viena iš serijos policijos sargybos viršininko Gustavo Hille's darytu nuotraukų, oficialaus Vokietijos teisėsaugos tyrimo metu identifikuotų kaip fotografuotų likviduojant Mizočo (Lenkija) getą ${ }^{82}$. Šio įvykio nuotraukos archyvuose taip pat paplitusios ivvairiais pavadinimais, tačiau niekur nepriskiriamos Lietuvai.

Tas pat pavadinimas ir dar vienos nuotraukos. Čia jaunas vaikinas su ginklu veda už parankès nuogą moterį ${ }^{83}$. Šioji iš Yad Vashem archyvų atsiranda ir Dovo Levino litvaku istorijoje, kur netgi nurodoma ịvykio vieta - Babtai ${ }^{84}$. Tačiau kaip ir su kitomis panašaus pobūdžio nuotraukomis, archyvuose ši vaizdą galima aptikti identifikuojamą skirtingose vietovėse, pavyzdžiui, Ghetto fighters house nurodo, jog tai Kalevi-Liiva žudynių vieta Estijoje $^{85}$.

Apie klaidingą iš Lietuvos emigravusių žydų (D. Levinas ir A. Faitelsonas - buvę Kauno geto kaliniai) leidiniuose naudojamų nuotraukų identifikavimą pažymi ir A. Eidintas ${ }^{86}$. I šią grupę taip pat įeina kareivių akivaizdoje ant žemės klūpinčias ir nusirenginėjančias žydes fiksuojanti fotografija, D. Levino ir A. Faitelsono siejama su Rokiškiu ${ }^{87}$. Čia įdomu ir tai, kad nuotrauka pasirodè dar sovietinėje istoriografijoje ${ }^{88}$, o apie tai, kad tai ne tik tas pat vaizdas, bet ir ta pati kopija, leidžia spèti nuotraukos kokybė (matyti pieštuku paryškintos detalès, identiškas vaizdo apkarpymas). Pagal USHMM archyvo informaciją, ši populiari nuotrauka ir dar dvidešimt šešios iškart po karo buvo atsitiktinai rastos viename privačiame albume Sosnovece, ir didžiausia tikimybė, jog vaizduoja ịvykius po nacių invazijos

81 Alex Faitelson, op. cit., p. 41.

82 „Naked Jewish women, some of whom are holding infants, wait in a line before their execution by Ukrainian auxilliary police“, [interaktyvus], https://collections.ushmm.org/search/catalog/ pa1065461, [žiurrèta 2020-08-28]; taip pat Mass shootings. The Holocaust from the Baltic to the Black sea 1941-1944: Parodos katalogas, sud. Uwe Neumärker, Berlin: Topographie des Terrors, 2016, p. 74.

83 Alex Faitelson, op. cit., p. 41.

84 Dov Levin, op. cit., p. 219.

85 „The execution of a Jewish woman in the Kalevi-Liiva extermination site in Estonia“, in: Ghetto Fighters House Archives, [interaktyvus], http://www.infocenters.co.il/gfh/notebook_ext. asp?item $=1090 \&$ site $=$ gfh \&lang $=$ ENG\&menu $=1$, [žiürèta 2020-08-28].

86 Lietuvos žydu žudyniu byla: dokumentu ir straipsniu rinkinys, il. 19-21; Alfonsas Eidintas, op. cit., il. 34-36.

87 Alex Faitelson, op. cit., p. 47; Dov Levin, op. cit., p. 220.

88 Hitlerinè okupacija Lietuvoje, p. 83 - Žydužzudynès Rokiškyje 1941 metu vasara. 


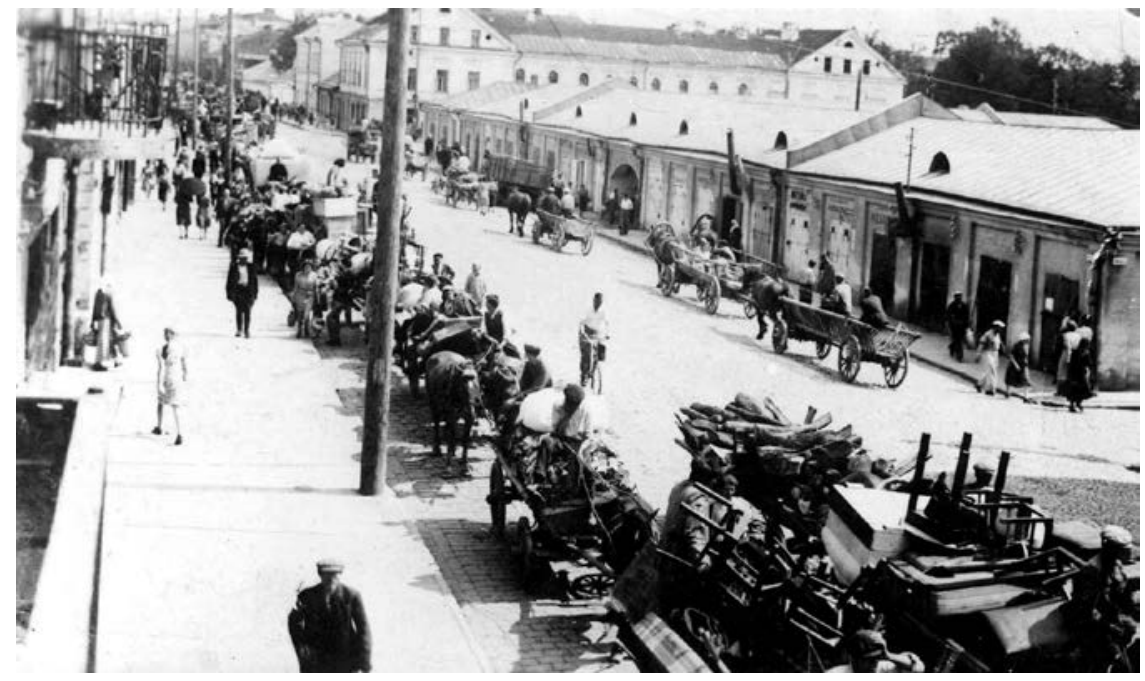

5.

Nežinomas fotografas, Vežimai su žydų, besikraustančių ị Vilijampolèje įkurtą Kauno getą, daiktais. Dešinėje - tuščių vežimų kolona grịžta ị miesto centrą, $1941 \mathrm{~m}$. rugpjūtis, nuotrauka, Yad Vashem archyvas.
Unknown photographer, Carts with the belongings of the Jews being moved to the Kaunas ghetto in Vilijampole, August 1941

i Lenkiją 1939 metais $^{89}$. Tačiau užsienio žydu autoriai ne vieninteliai, kurių skelbiamų nuotraukų autentiškumu galima suabejoti.

Kontroversiškai vertinami Rūtos Vanagaitès Mūsiškiai kelia nemažai klausimų ir dèl iliustracijoms pasitelktų nuotraukų. Tai, kad knygos nugarèlejje ir 94-ame puslapyje išspausdinta nuotrauka Žydu vyrai laukia šūvio yra ne tik nelietuviška - ji vaizduoja ne žydų, o serbų sušaudymą, teigia Irena Tumavičiūtè ${ }^{90}$. Dar pora nuotraukų, pavadintų Šaudymo aki$m i r k a^{91}$, yra iš gerai žinomų ir dokumentuotų žudynių prie Liepojos $1941 \mathrm{~m}$. gruodi, padarytos SS karininko Carlo Emilio Strotto ir slaptai nukopijuotos elektriko Davido Zivcono bei po karo panaudotos kaip įrodymai Niurnbergo teismuose ${ }^{92}$.

89 „German police and auxiliaries in civilian clothes look on as a group of Jewish women are forced to undress before their execution“, in: USHMM collections, [interaktyvus], 2019, https://collections.ushmm.org/search/catalog/pa1175556, [žiūrèta 2020-08-28].

90 Irena Tumavičiūtė, „Kodèl serbų žudynès iliustruoja ,MŪSIŠKIUS'?‘“, in: Voruta, 20160405 [interaktyvus], http://www.voruta.lt/irena-tumaviciute-kodel-serbu-zudynes-iliustruojamusiskius-2/, [žiūrèta 2020-08-28].

91 Rūta Vanagaitè, op. cit., p. 75, 180.

92 „The visual evidence of the murder of the Jews of Liepaja“, in: Yad Vashem, [interaktyvus], http://www.yadvashem.org/righteous/stories/sedul-schimelpfening/liepaja-murderevidence.html, [žiūrèta 2020-08-28]. 


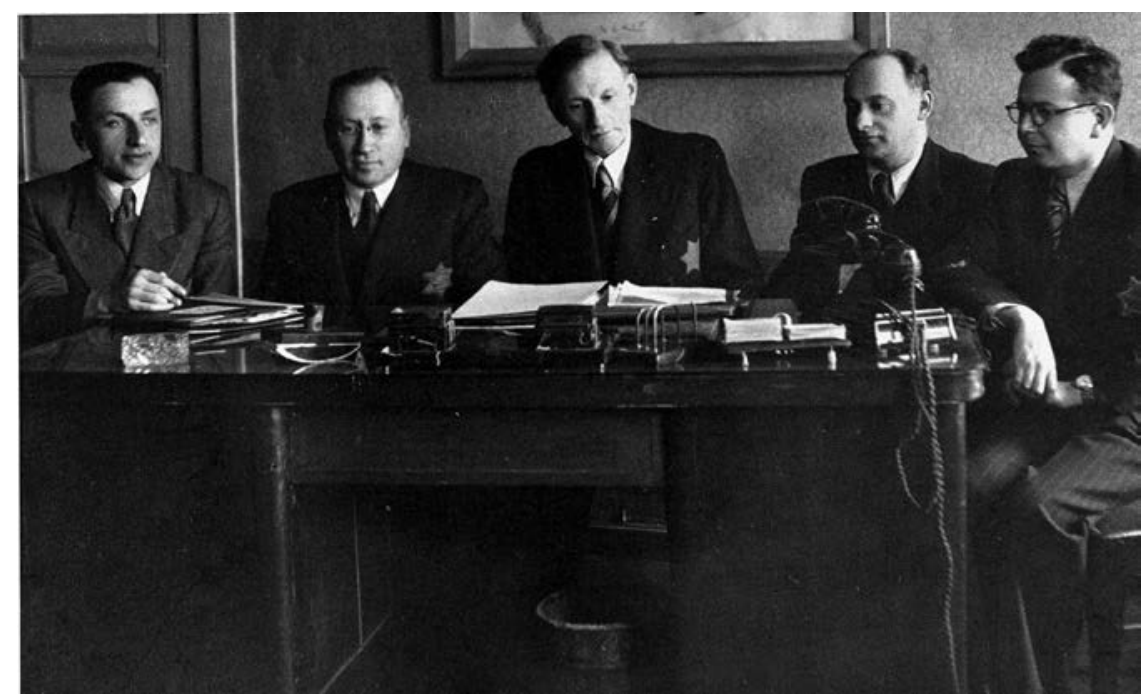

6.

Nežinomas fotografas, Kauno geto seniūnų tarybos (vok. Aeltestenrat) nariai administracijos pastate Varnių gatvèje. Iš kairès - tarybos sekretorius Avrahamas Golubas (vèliau Tory), pirmininko pavaduotojas Leibas Garfunkelis, pirmininkas dr. Elchananas Elkesas, darbo ịstaigos vadovas Jakovas Goldbergas, patarèjas Zvi Levinas. I kadrą nepateko, bet tarybai taip pat priklausė žydu policijos viršininkas Moisiejus Kopelmanas, Efraimas Rabinovičius, rabinai Šmuelis Aba Sniegas ir Jakovas Mošè Šmukleris, 1943, fotografija, United States Holocaust Memorial Museum (USHMM) archyvas
Unknown photographer, Members of the Kaunas Ghetto Council of Elders (Aeltestenrat) in the administrative offices on Varnių street, 1943

Žudynių vaizdai užfiksuoti dar dviejose nuotraukose. Vienoje matome dvi nuogas moteris stambiu planu (Prieš mirtį), o kitoje iš viršaus nufotografuotus nužudytujų kūnus duobėje (Žudyniu aukos, vietovè nežinoma $)^{93}$. Kad tai Kaune darytos nuotraukos, teigiama Yad Vashem archyve esančių kopijų aprašymuose ${ }^{94}$. Archyvui nuotraukas padovanojo buvęs Kauno geto kalinys, antinacinio pasipriešinimo dalyvis Eliezeris Zilberis. Tačiau nuotraukų atsiradimo aplinkybès lieka neaiškios; jog tai ne iš originalaus negatyvo darytos kopijos, išduoda pernelyg didelis kontrastingumas, be

93 Rūta Vanagaitè, op. cit., p. 99, 125.

94 „Kovno, Lithuania, Jewish women before their murder by Lithuanian militiamen“, in: Yad Vashem, [interaktyvus], http://collections1.yadvashem.org/notebook_ext. asp?item =6449\&site = sapir\&lang =ENG\&menu=1, [žiūrèta 2020-08-28]; „Kovno, Lithuania, Jewish women murdered by Lithuanian militiamen“, in: Yad Vashem, [interaktyvus], http://collections1. yadvashem.org/notebook_ext.asp?item $=11212 \&$ site=sapir\&lang=ENG\&menu=1, [žiūrèta 2020-08-28]. 
to, toje pačioje kolekcijoje yra ir jau aptarta vaikino, vedančio nuogą žydę, nuotrauka, kuri, kaip išsiaiškinome, siejama su Estija, o čia taip pat identifikuojama Kaune.

R. Vanagaitè kaip visų šių nuotraukų šaltinį nurodė Lietuvos ypatingaji archyvą (toliau - LYA), tačiau konkrečių nuorodų nepateikè. Fotografijas (tiksliau - originalų reprodukcijas) pavyko aptikti KGB byloje, skirtoje medžiagai apie Panerių žudynes ${ }^{95}$. Sovietines institucijas, kaip ir visą sistemą, labiau nei tiksli istorinè dokumentacija domino emocinis šiurpios iliustracijos efektas, o tikrovė nublanko prieš subjektyviai suvokiamą „tiesą ${ }^{“ 96}$, tad šio laikotarpio archyvus reikia vertinti su ypatinga atida.

KGB bylose saugomos nuotraukos tariamai iš Panerių yra surinktos iš kitų šaltinių ir sąmoningai pervadintos ideologiniais tikslais, todèl neturètų būti naudojamos istoriniuose naratyvuose kaip šios vietos ar Holokausto Lietuvoje iliustracija. Čia taip pat galima ginčytis, jog prierašai po nuotraukomis Žydu vyrai laukia šūvio; Šaudymo akimirka; Prieš mirtį; Žudyniu aukos ir pan. nebūtinai teigia scenas esant iš Lietuvos. Tačiau tuomet kyla klausimas: koks tokių nuotraukų publikavimo tikslas? Kadangi neįvardijamos net paprasčiausios nuotraukose vaizduojamų ịvykių konkretybės (laikas ir vieta), savaime apeliuojama ne ị protą, o ị emocijas. 0 tokiu atveju, kaip teigia S. A. Crane, tik sukrečiami jutimai, tačiau nuotrauka nemoko prasmių kūrimo ar istorinio tikroviškumo bei rizikuoja virsti kiču ${ }^{97}$.

S. Atamuko knygoje Lietuvos žydu kelias: nuo XIV a. iki XXI a. pradžios skaitytoją pasitinka trijų nuotraukų serija pavadinimu Vokiečiai šaudo Šiauliu žydus (SS karininko nuotraukos) ${ }^{98}$. Vèliau pora iš šių nuotraukų panašiais pavadinimais, tačiau nenurodant šaltinio, pasirodè ir kituose lietuviškuose leidiniuose ${ }^{99}$. Viename kadre užfiksuoti duobę kasantys vyrai, stebimi vokiečių kareivių, kitame - prie duobės krašto sustatyti vyrai stambiu planu, o trečiame - jau kita vyru grupè ant duobės krašto, nufotografuota iš toliau, matyti jiems ị pakaušius ịremti kareivių ginklai. Kad

95 Valstybės saugumo komiteto (KGB) prie Lietuvos TSR Ministrų Tarybos Tardymo skyriaus $1964 \mathrm{~m}$. sudaryta byla pavadinimu LTSR KGB operatyviness grupés surinkti dokumentai apie asmenis, bendradarbiavusius su Vokietijos okupacine valdžia ar užsienio žvalgybos tarnybomis, lietuviu tautinio pogrindžio dalyvius. Dokumentai ir nuotraukos apie Paneriu žudynes, in: LYA, f. K-40, ap. 1, b. 190.

96 D. Shneer, Trough Soviet Jewish Eyes, p. 53-54.

97 Susan A. Crane, op. cit., p. 316.

98 Solomonas Atamukas, Lietuvos žydu kelias: nuo XIV a. iki XXI a. pradžios, p. 254.

99 Arūnas Bubnys, The Holocaust in Lithuania between 1941 and 1944, p. 12; Lietuva, 1940-1990: okupuotos Lietuvos istorija, p. 220. 
tai to paties įvykio scenos, galime spręsti iš nuotraukose matomo to paties kraštovaizdžio (smèlio kalvos ir pavienès pušys) bei fone veiksmą stebinčių kareivių. Tačiau nuotraukų priskyrimas Kužių miškui šalia Šiaulių yra diskutuotinas.

S. Atamukas kaip šių nuotraukų šaltini nurodo jidiš kalba išleistą Dos shvartse bukh (Juodoji knyga) ${ }^{100}$, tačiau originalų, žinoma, reikia ieškoti archyve. Juos aptinkame Yad Vashem archyve, kur jie taip pat identifikuojami Kužių miške prie Šiaulių, tačiau tai nėra originalai, neaiškus nuotraukų ịsigijimo šaltinis ${ }^{101}$.

Tos pačios trys nuotraukos priklauso ir kitai Yad Vashem archyvo kolekcijai, kurioje surinktos fotografijos iš ịvairių Rusijos archyvų. Jos aprašyme yra ir perspejjimas, kad pateikiami prierašai daugeliu atvejų yra netikslūs, todèl turètų būti vertinami apdairiai ${ }^{102}$. Čia „Šiaulių“ fotografijos identifikuojamos tik su SSRS teritorija, neminint Lietuvos. Griovio kasimo scena taip pat pasirodo kolekcijoje, surinktoje iš Rusijos valstybinio kino ir fotodokumentų archyvo (toliau - RGAKFD), ir įvardijama kaip ko gero Šiauliai ${ }^{103}$, taip pat apytiksliai identifikuojama ir scena su ịremtais i auku pakauši ginklais, dar kitoje archyvo kolekcijoje, kur vaizdai nukopijuoti iš to paties RGAKFD ${ }^{104}$.

Taigi galima numanyti, kad pirminè nuotraukos saugojimo vieta yra būtent Rusijoje. Fotodokumentai iš buvusios SSRS archyvų kelia ypač nemaža rūpesčių, mat užfiksuota daug atvejų, kai istorinėms nuotraukoms

100 Dos shvartse bukh, sud. Vasily Grossman, Ilya Ehrenburg, Jerusalem: Yad Vashem, 1984.

101 „Probably Siauliai, Lithuania, Men standing in line before their execution; behind them are SS soldiers“, in: Yad Vashem, [interaktyvus], http://collections1.yadvashem.org/notebook_ext. asp?item $=83551 \&$ site $=$ sapir\&lang $=$ ENG\&menu=1, [žiūrèta 2020-08-28]; „Probably Siauliai, Lithuania, Jewish men before their execution“, in: Yad Vashem, [interaktyvus], http://collections1. yadvashem.org/notebook_ext.asp?item =29289\&site=sapir\&lang $=$ ENG\&menu=1, [žiūrèta 202008-28]; „Probably Siauliai, Lithuania, Digging of graves before an execution by members of an Einsatzgruppe in the Kuziai Forest“, in: Yad Vashem, [interaktyvus], http://collections1.yadvashem. org/notebook_ext.asp?item =3017\&site=sapir\&lang =ENG\&menu=1, [žiūrèta 2020-08-28].

102 „Photos from different Soviet archives“, in: Yad Vashem, [interaktyvus], http:// collections1.yadvashem.org/notebook_ext.asp?item $=11890143 \&$ site=sapir\&lang $=$ ENG\&menu=1, [žiūrèta 2020-08-28].

103 „Probably Siauliai, Lithuania, Digging graves in the Kuziai Forest“, in: Yad Vashem, [interaktyvus], http://collections1.yadvashem.org/notebook_ext. asp?item $=59745 \&$ site $=$ sapir\&lang $=\mathrm{ENG \& menu}=1$, [žiūrèta 2020-08-28].

104 „Probably Siauliai, Lithuania, A German soldier photographing prisoners being led to their execution, 1941“, in: Yad Vashem, [interaktyvus], http://collections1.yadvashem.org/notebook ext.asp?item $=78963 \&$ site $=$ sapir\&lang $=$ ENG\&menu $=1$, [žiūrèta 2020-08-28]. 


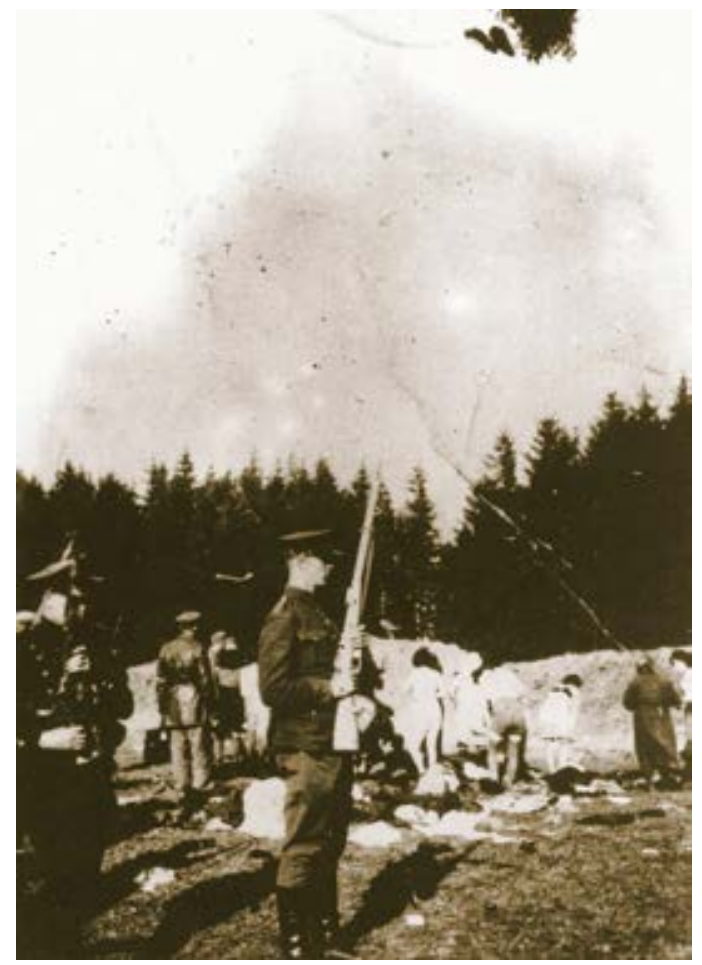

7.

Nežinomas fotografas, Kadras iš Pajuostès miške vykdytų žudynių likviduojant Panevėžio getą. Nufotografuoti asmenys nenustatyti, su šautuvu stovi lietuvių policijos bataliono kareivis. Fone prieš egzekuciją nusirengiantys žydai; jų drabužius ir kitus asmeninius daiktus vèliau išsidalydavo žudynių vykdytojai, 1941 m. rugpjūtis, fotografija, USHMM archyvas

Unknown photographer, Photograph of the massacre in the Pajuoste forest during the liquidation of the Panevėžys ghetto, August 1941

buvo suteiktos klaidingos atribucijos ${ }^{105}$. Kadangi aptariamose „Šiaulių“ nuotraukose neidentifikuotas nei autorius, nei kuris nors iš nufotografuotujų, o vienintelè informacija yra neaiškiomis aplinkybèmis suteikta oficialios SSRS institucijos, negalime teigti, kad užfiksuotas vaizdas tikrai yra iš Kužių miško, ar kad matome būtent Šiaulių žydų egzekuciją.

Kaip visiškas nesusipratimas atrodo bestseleriu tapusioje vokiečių istoriko Ernsto Klee pagal nacių nusikaltimų liudytojų parodymus sudarytoje knygoje The Good Old Days... išspausdinta nuotrauka. Joje, anot prierašo, matyti miško aikštelėje žydai, verčiami kasti masinio kapo duobę, o fone guli jau nušauti žydai, ir visa tai vyksta 1941-ujų vasarą Lietuvoje ${ }^{106}$. Autorius šaltinio nenurodo, tačiau paieška Yad Vashem archyve atskleidžia,

105 Ryškiausias pavyzdys - 1995 m. Hamburge atidaryta istorinių fotografijų paroda Vernichtungskrieg. Verbrechen der Wehrmacht 1941 bis 1944, plačiau žr. Crimes of the German Wehrmacht: Dimensions of a War of Annihilation 1941-1944: An outline of the exhibition, sud. M. Wildt, U. Jureit, B. Otte, Hamburg Institute for Social Research, 2004, p. 34-36, [interaktyvus], http://www.verbrechen-der-wehrmacht.de/pdf/vdw_en.pdf , [žiūrèta 2020-08-28].

106 „The Good Old Days“: The Holocaust as Seen by Its Perpetrators and Bystanders, p. 55. 


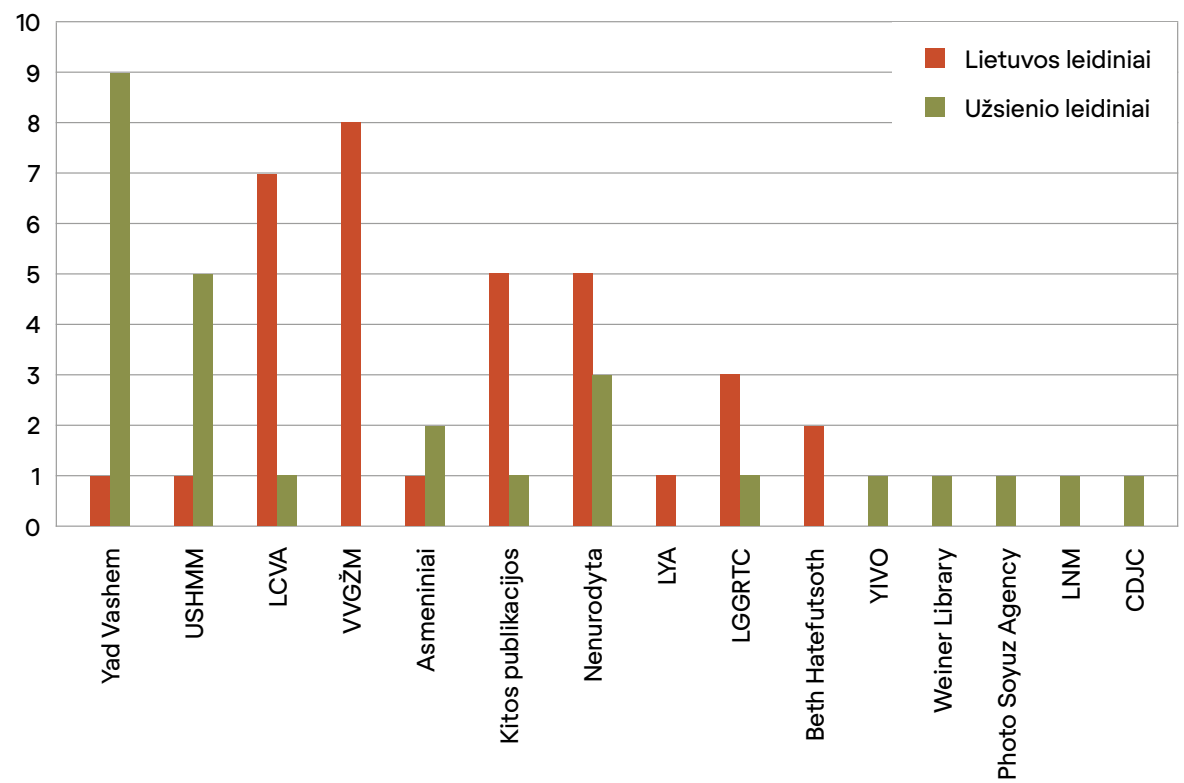

\section{1 diagrama}

Tiriamieji leidiniai pagal publikuojamu nuotrauku šaltinius. Stulpeliai rodo, keliuose leidiniuose panaudoti vaizdai iš apačioje ịvardytų šaltinių

\section{Diagram 1}

Research publications according to the sources of published photographs a)

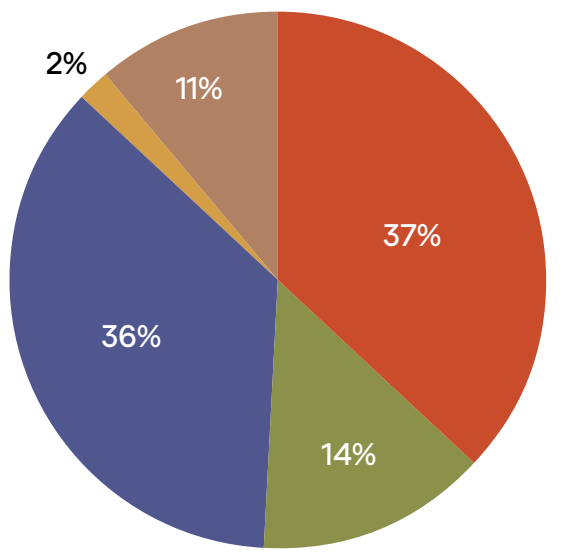

naciai

sovietai

žydai

\section{2 diagrama}

a) nuotrauku autorių perspektyvos Lietuvos leidiniuose, b) užsienio leidiniuose. Nurodyta procentinè dalis iš bendro tirtų nuotraukų skaičiaus (atitinkamai 191 ir 115) b)

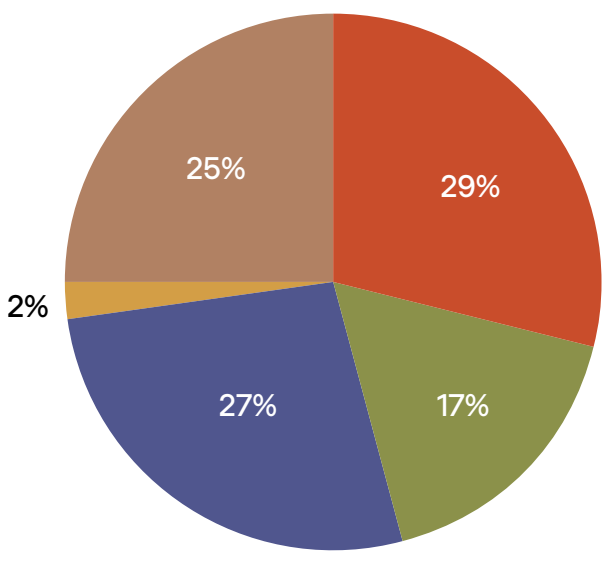

lietuviai

\section{Diagram 2}

Perspectives of the authors of photographs in Lithuanian publications (left) and international publications (right) 
kad nuotraukoje užfiksuota NKVD nužudytų kalinių ekshumacija Zolochive (buv. Lenkija, dab. Ukraina) ${ }^{107}$.

K. Sutton knygoje The Massacre of the Jews of Lithuania... nuotrauka Žydu pažeminimas vaizduoja grupę žmonių miesto gatvėje, o ryškiausiai matomas i medinius ratus issodintas rabinas, laikantis plakata su neįskaitomu tekstu ${ }^{108}$. Tačiau iš tikrujų veiksmas vyksta ne Lietuvoje, o Lodzėje. Šio miesto muziejaus tinklapyje skelbiamoje toje pačioje nuotraukoje galima įžiūrèti plakate užrašytą tekstą lenkų kalba ${ }^{109}$.

Taip pat aptiktos kelios nuotraukos, kur prierašuose pateikta ne esmingai keičianti interpretacija, bet šiek tiek klaidinanti informacija. Pavyzdžiui, S. Atamukas vieną C. H. Kadušino nuotrauką klaidingai priskiria Vilniaus getui, o Lietuvos žydu istorinès studijos autoriai, remdamiesi nepatikrintais Beit Hatfutsot archyvo duomenimis, mano, jog pogrome Vilijampolèje (1941 m. birželio 25 d.) užfiksuotas sinagogoje nužudytas rabinas vaizduoja Kauno geto ješivą, ir C. H. Kadušiną pavadina nežinomu fotografu $^{110}$. A. Eidintas ${ }^{111}$ jau minètą fotografiją iš Pajuostès prie Panevėžio dèl nežinomų priežasčių priskiria Paneriams.

Siekiant išvengti panašių nesusipratimų, galima pasiūlyti ir sprendimą. Renkantis nuotraukas būtina atkreipti dèmesị, kiek yra papildomos informacijos, garantuojančios vaizdo autentiškumą. Identifikuoti asmenys, autorius, tikslus ịvykis ar data liudija fotografijos patikimumą. Taip pat nuorodų gali suteikti vizualūs ženklai, pavyzdžiui, konkrečiai vietai būdingi pastatai, nufotografuotų objektų sutapimas su kita, tiksliai identifikuota, nuotrauka. Abejotinos kilmès vaizdus būtina patikrinti įvairiuose archyvuose, kur neretai išaiškejja visai skirtingos tos pačios nuotraukos atribucijos. Patikimiausia informacija visada yra ta, kur tiksliai nurodomos ir nuotraukos atsiradimo bei suradimo aplinkybès.

107 „Poland, Zloczow, Exhumation of prisoners bodies who were murdered by the NKVD prior to the retreat of the Soviets from the area, summer of 1941“, in: Yad Vashem, [interaktyvus],

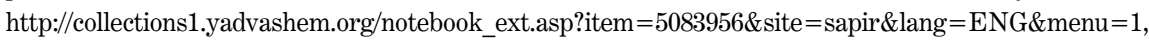
[žiūrèta 2020-08-28].

108 Karen Sutton, op. cit., p. 47.

109 „Polityka wobec ludności żydowskiej“, in: Wirtualne muzeum Dziedzictwo Żydów Łódzkich, [interaktyvus], http://museum.lodzjews.org/pl/02-polityka-wobec-ludno\%C5\%9Bci\%C5\%BCydowskiej, [žiūrèta 2020-08-28].

110 Lietuvos žydai: istorine studija, sud. Vladas Sirutavičius, Darius Staliūnas, Jurgita Verbickienè, Vilnius: Lietuvos istorijos institutas, 2012.

111 Alfonsas Eidintas, Žydai, lietuviai ir Holokaustas; Lietuvos žydu žudyniu byla: dokumentu ir straipsniu rinkinys. 


\begin{tabular}{l|l|l}
\hline Tema & $\begin{array}{l}\text { Santykinè dalis } \\
\text { Lietuvos leidiniuose }\end{array}$ & $\begin{array}{l}\text { Santykinè dalis } \\
\text { užsienio leidiniuose }\end{array}$ \\
\hline Žydų žudynès ir pažeminimas & $65 \%$ & $81 \%$ \\
\hline Gyvenimas getuose & $90 \%$ & $56 \%$ \\
\hline Antinacinis pasipriešinimas & $20 \%$ & $37,5 \%$ \\
\hline Portretai & $55 \%$ & $19 \%$ \\
\hline Nacių okupacinė valdžia & $35 \%$ & $12,5 \%$ \\
\hline Lietuvių kolaborantai & $15 \%$ & $12,5 \%$ \\
\hline Lietuvių visuomenė & $35 \%$ & $12,5 \%$ \\
\hline Ekshumacija & $15 \%$ & $12,5 \%$ \\
\hline Vietos & $40 \%$ & $12,5 \%$ \\
\hline Griuvėsiai & $40 \%$ & \\
\hline
\end{tabular}

1 lentelè

Lietuvos ir užsienio leidiniuose paskelbtos nuotraukos pagal turinį. Procentai rodo, kokioje dalyje leidinių aptiktos tam tikrą temą pagrindžiančios nuotraukos
Table 1

Photographs published in Lithuanian and international publications according to their contents

\section{Išvados}

Pagrindinè tyrimo išvada - tiek užsienio, tiek Lietuvos leidiniuose, perteikiančiuose Holokausto mūsų šalyje temą, matyti dažniausiai paviršutiniškas fotografinių istorinių šaltinių traktavimas. Tai liudija vyraujantys tiek abstraktūs, tiek trumpi ar net klaidingi nuotraukų prierašai, vengimas ivvardyti originalias vaizdu atsiradimo aplinkybes, jų autorius, o neretai nurodyti šaltini. Tokia padètis lemia, kad publikacijose naudojamos fotografijos neprisideda prie gilesnio istorinio Holokausto Lietuvoje pažinimo, o kai kuriais atvejais klaidina, ypač kai, nekritiškai pasikliaujant archyvais, pateikiamos nepakankamai kruopščiai išstudijuotos nuotraukos, iš tikruju neturinčios nieko bendro su Lietuva. 
Šio straipsnio ir jame pristatomo tyrimo tikslas nèra ịvertinti, ar Holokaustas vaizduojamas tinkamai, remiantis istoriografijai parinktomis fotografijomis, ir juo labiau moralizuoti nagrinètos literatūros autorius. Tik siekta apibrèžti Holokausto Lietuvoje tematiką nagrinejjančioje literatūroje (tiek mokslinėje, tiek populiariojoje) naudojamų vaizdų charakteristiką. Tad, nuotraukas išnagrinėjus ir sugrupavus bendroje lentelèje, galima mèginti apibūdinti ir statistinę lietuvišką Holokaustą vaizduojančią nuotrauką. Užsienyje tai nacių užfiksuotas žudynių vaizdas iš Kauno su informuojančiu, bet kartu kuriančiu ir simbolinę reikšmę, prierašu, pabrèžiant lietuvių dalyvavimą, gautas iš Yad Vashem archyvo. Lietuvoje C. H. Kadušino nuotrauka iš Kauno geto tik su vietos, laiko ir ịvykio informacija, bet nenurodant autoriaus ar pavaizduotų asmenų, gauta iš VVGŽM fondų.

Pasauliniame kontekste, kur, reprezentuojant Holokaustą, vyrauja pačių nacių sukurti vaizdai, Lietuvos situacija tampa unikali būtent dèl Kauno gete kalëjusio ir ji fotografavusio C. H. Kadušino. Jo nuotraukų egzistavimas ir plati sklaida tiek užsienio, tiek Lietuvos archyvuose lemia kelis esminius mūsų šalyje vykusio Holokausto fotografinės reprezentacijos bruožus - pasakojimą iš žydų, taigi aukų pusės, absoliutų vaizdų iš Kauno vyravimą ir ryškiai išreikštą gyvenimo gete temą.

Tačiau Lietuvoje vis dar nesiaiškintos nei C. H. Kadušino gyvenimo, nei nuotraukų atsiradimo ir tolesnio likimo aplinkybės, o fotografijos inertiškai publikuojamos nenurodant autoriaus, nesivarginant ịvardyti konkrečiu asmenų, kurie dažnu atveju gali būti atsekami, todèl ribojamas pažinimui būtinas kritinis santykis vaizdų atžvilgiu, šios svarbios nuotraukos lieka neicvertintos ir neapmąstytos.

Taigi išaiškejjusi situacija rodo aiškų istorinių tyrimų, skirtų fotografijų atsiradimo ir vėlesnės sklaidos aplinkybėms aiškintis, poreikị. Tuomet taps įmanoma išskleisti visą istorinių fotografijų potencialą perteikiant konkrečiu Holokaustą sudarančių îvykių ir jų dalyvių patirtis bei suvokimą.

Gauta -20201030

$99-2020$

Acta Academiae Artium Vilnensis 


\section{Literatūra ir šaltiniai}

Anušauskas Arvydas, Sviderskytė Gražina, XX amžiaus slaptieji archyvai. Dvylika istorijos detektyvu, Vilnius: Versus aureus, 2008.

Atamukas Solomonas, Lietuvos žydu kelias: nuo XIV a. iki XXI a. pradžios, Vilnius: Alma littera, 2001.

Atamukas Solomonas, Žydai Lietuvoje XIVXX amžiais, Vilnius: Lituanus, 1990.

Baranova Olga, „Politics of Memory of the Holocaust in the Soviet Union“, in: Dimensions of Modernity. The Enlightenment and its Contested Legacies, ed. P. Marczewski, S. Eich, Vienna: IWM Junior Visiting Fellows' Conferences, 2015, Nr. 34, [interaktyvus], http://www.iwm.at/publications/5-junior-visiting-fellows-conferences/vol-xxxiv/ politics-of-memory-of-the-holocaust-in-thesoviet-union/, [žiūrèta 2020-08-28].

Berenbaum Michael, The World Must Know: The History of the Holocaust as Told in the United States Holocaust Memorial Museum, Boston: Little \& Brown, 1993.

Bergen Doris L., War and Genocide: A Concise History of the Holocaust, 3rd ed., Lanham: Rowman \& Littlefield, 2016.

Berkhoff Karel C., „Total Annihilation of the Jewish Population: The Holocaust in the Soviet Media, 1941-45“, in: The Holocaust in the East: Local Perpetrators and Soviet Responses, sud. Michael David-Fox, Patirc Holquist, Pittsburgh: University of Pittsburgh Press, 2014, p. 83-117.

Bernard-Donals Michael F., Forgetful Memory: Representation and Remembrance in the Wake of the Holocaust, New York: State University of New York, 2009.

Bubnys Arūnas, The Holocaust in Lithuania between 1941 and 1944, Vilnius: LGGRTC, 2011.

Bubnys Arūnas, Vokiečiu okupuota Lietuva (1941-1944), Vilnius: LGGRTC, 1998.

Bubnys Arūnas, „Trumpa holokausto Lietuvoje istorija, istoriografija ir bibliografija“, in:
Lietuvos gyventoju genocido ir rezistencijos tyrimu centras, [interaktyvus], http:// genocid.lt/centras/lt/891/a/, [žiūrèta 202008-28].

Buettner Angi, Holocaust Images and Picturing Catastrophe: The Cultural Politics of Seeing, Farnham: Ashgate, 2011.

Cohen Judith, „Jewish Ghetto Photographers“, in: The Holocaust: Memories and History, sud. Victoria Khiterer et al., Cambridge: Cambridge Scholars Publishing, 2014.

Crane Susan A., „Choosing Not to Look: Representation, Repatriation, and Holocaust Atrocity Photography“, in: History and Theory, 2008, Nr. 47, p. 309-330, [interaktyvus], http://www.jstor.org/stable/25478766, [žiūrèta 2020-08-28].

Crimes of the German Wehrmacht: Dimensions of a War of Annihilation 1941-1944: An outline of the exhibition, exhibition brochure editors: Dr. Michael Wildt, Dr. Ulrike Jureit, Birgit Otte, English version: Paula Bradish, Hamburg: Hamburg Institute for Social Research, 2004, [interaktyvus], file://C:/Users/Owner/Downloads/crimesof-the-german-wehrmacht.pdf, [žiūrèta 2021-03-07].

Dos shvartse bukh, sud. Vasily Grossman, Ilya Ehrenburg, Jerusalem: Yad Vashem, 1984.

Documents Accuse, sud. B. Baranauskas, K. Rukšènas, Vilnius: Valstybinè politinès ir mokslinès literatūros leidykla, 1970.

Eglinis M., Gelpernas Dmitrijus, Kauno getas ir jo kovotojai, Vilnius: Mintis, 1969.

Eidintas Alfonsas, Žydai, lietuviai ir Holokaustas, Vilnius: Vaga, 2002.

Faitelson Alex, Heroism \& Bravery in Lithuania 1941-1945, Jerusalem: Gefen Publishing House, 1996.

„German police and auxiliaries in civilian clothes look on as a group of Jewish women are forced to undress before their execution“, in: USHMM collections, [interaktyvus], 2019, https://collections.ushmm. org/search/catalog/pa1175556, [žiūrèta 2020-08-28]. 
Ginaitė Sara, Atminimo knyga, Vilnius: Margi raštai, 1999.

Goldhagen Daniel Jonah, Hitler's Willing Executioners: Ordinary Germans and the Holocaust, New York: Random house, 1997.

Hirsch Mariene, „Surviving Images: Holocaust Photographs and the Work of Postmemory“, in: Visual Culture and the Holocaust, ed. Barbie Zelizer, London: Rutgers University Press, 2001.

Hitlerine okupacija Lietuvoje, Vilnius: Valstybinè politinès ir mokslinès literatūros leidykla, 1961.

Kadish George et al., Days of Remembrance, 198\%: Family Life in the Kovno Ghetto, San Francisco: Mellen Research University Press, 1991.

Kapleris Ignas et al., XX a. Lietuvos ir pasaulio istorija, Vilnius: Briedis, 2009.

Keilbach Judith, „Photographs, Symbolic Images, and the Holocaust: On the (im) possibility of depicting historical truth“, in: History and Theory, 2009, Nr. 2 (48), p. 54-76, [interaktyvus], http://www.jstor. org/stable/25478837, [žiūrèta 2020-08-28].

Khiterer Victoria, „Introduction“, in: The Holocaust: Memories and History, edited by Victoria Khiterer with Ryan Barrick, David Misal, Cambridge: Cambridge Scholars Publishing, 2014, p. xii-xix.

„Kovno, Lithuania, Jewish women before their murder by Lithuanian militiamen“, in: Yad Vashem, [interaktyvus], http://collections1. yadvashem.org/notebook_ext.asp?item $=6449 \&$ site $=$ sapir\&lang $=$ ENG\&menu=1, [žiūrèta 2020-08-28].

„Kovno, Lithuania, Jewish women murdered by Lithuanian militiamen“, in: Yad Vashem, [interaktyvus], http://collections1. yadvashem.org/notebook_ext.asp?item $=11212 \&$ site $=$ sapir\&lang $=$ ENG\&menu=1, [žiūrèta 2020-08-28].

Levin Dov, The Litvaks: A Short History of the Jews in Lithuania, Jerusalem: Yad Vashem, 2000.

Levin Judith, Uziel Daniel, „Ordinary Men, Extraordinary Photos“, in: Yad Vashem
Studies, 1998, Nr. 26, p. 280-293, [interaktyvus], http:/www.yadvashem.org/odot_pdf/ Microsoft\%20Word\%20-\%202290.pdf, [žiūrèta 2020-08-28].

Lieberman Chaim, „Foreword“, in: Efroim Oshry, Hurbm Lite, Nyu York: aroysgegebn fun ha-Rav E. Oshri bukh ḳomițet, 1951, p. 467.

Lietuva 1940-1990: okupuotos Lietuvos istori$j a$, sud. Arvydas Anušauskas et al., Vilnius: LGGRTC, 2005.

Lietuvos istorija: enciklopedinis iliustruotas leidinys, Vilnius: Mokslo ir enciklopediju leidybos centras, 2010.

Lietuvos žydai: istorine studija, sud. Vladas Sirutavičius, Darius Staliūnas, Jurgita Verbickienè, Vilnius: Lietuvos istorijos institutas, 2012.

Lietuvos žydu žudyniu byla: dokumentu ir straipsniu rinkinys, sud. Alfonsas Eidintas, Vilnius: Vaga, 2001.

Löw Andrea, „Documenting as a 'Passion and Obsession': Photographs from the Lodz (Litzmannstadt) Ghetto“, in: Central European History, t. 48, Nr. 3, 2015, p. 387-404, [interaktyvus], https://doi.org/10.1017/ S0008938915000801, [žiūrèta 2020-08-28].

LTSR KGB operatyvines grupés surinkti dokumentai apie asmenis, bendradarbiavusius su Vokietijos okupacine valdžia ar užsienio žvalgybos tarnybomis, lietuviu tautinio pogrindžio dalyvius. Dokumentai ir nuotraukos apie Paneriu žudynes, in: LYA, f. K-40, ap. 1, b. 190.

Matulytė Margarita, Narušytė Agnė, Camera obscura: Lietuvos fotografijos istorija 1839-1945, Vilnius: Vilniaus dailès akademijos leidykla, 2016.

Masinès žudynès Lietuvoje, d. I, sud. G. Erslavaitè, K. Rukšènas, Vilnius: Valstybinè politinès ir mokslinės literatūros leidykla, 1965.

Masinès žudynès Lietuvoje, d. 2, sud. G. Erslavaitè, Vilnius: Valstybinè politinès ir mokslinès literatūros leidykla, 1973.

Mass Shootings. The Holocaust from the Baltic to the Black Sea 1941-1944: Parodos
99 2020

Acta Academiae Artium Vilnensis 
katalogas, sud. Uwe Neumärker, Berlin:

Topographie des Terrors, 2016.

Milton Sybil, „Photography as evidence of the

Holocaust", in: History of Photography, 1999, Nr. 4 (23), p. 303-312, [interaktyvus], https://doi.org/10.1080/03087298.1999.10443 338, [žiūrèta 2020-08-28].

Moss Mark, Toward the Visualization of

History: The Past as Image, Plymouth:

Lexington Books, 2010.

Mulevičiūtè Jolita, Besotis žvilgsnis. Lietuvos dailè ir vizualioji kultūra. 1865-1914, Vilnius: Lietuvos kultūros tyrimų institutas, 2012.

„Naked Jewish women, some of whom are holding infants, wait in a line before their execution by German Sipo and SD, with the assistance of Ukrainian auxiliaries“, in: USHMM collections, [interaktyvus], 2019, https://collections.ushmm.org/search/catalog/pa1065461, [žiūrèta 2021-03-01].

„Photos from different Soviet archives“, in: $Y a d$ Vashem, [interaktyvus], http://collections1. yadvashem.org/notebook_ext.asp?item $=11890143 \&$ site $=$ sapir\&lang $=\mathrm{EN}-$ G\&menu=1, [žiūrèta 2020-08-28].

„Poland, Zloczow, Exhumation of prisoners bodies who were murdered by the NKVD prior to the retreat of the Soviets from the area, summer of 1941“, in: Yad Vashem, [interaktyvus], http://collections1.yadvashem. org/notebook ext.asp?item $=5083956 \&$ site $=$ sapir\&lang $=\mathrm{ENG \& menu}=1$, [žiūrèta 2020-08-28].

„Polityka wobec ludności żydowskiej“, in: Wirtualne muzeum Dziedzictwo Żydów Łódzkich, [interaktyvus], http://museum. lodzjews.org/pl/02-polityka-wobec-ludno\%C5\%9Bci-\%C5\%BCydowskiej, [žiūrèta 2020-08-28].

„Ponary, Poland, Jews who were led to the place they will be executed by Lithuanian militiamen“, 1941, in: Yad Vashem, [interaktyvus], http://collections1.yadvashem. org/notebook_ext.asp?item $=100107 \&$ site $=$ sapir\&lang $=\mathrm{ENG \& menu}=1$, [žiūrèta 2020-08-28].
„Ponary, Poland. Two Jews just before their execution, surrounded by German soldiers, June-July 1941“, in: Yad Vashem, [interaktyvus], http://collections1.yadvashem. org/notebook_ext.asp?item $=100101 \&$ site $=$ sapir\&lang $=$ ENG\&menu $=1$, [žiūrèta 2020-08-28].

„Probably Siauliai, Lithuania, Men standing in line before their execution; behind them are SS soldiers", in: Yad Vashem, [interaktyvus], http://collections1.yadvashem.org/ notebook_ext.asp?item $=83551 \&$ site $=$ sapir\&lang $=\mathrm{ENG \& menu}=1$, [žiūrèta 2020-08-28].

„Probably Siauliai, Lithuania, Jewish men before their execution“, in: Yad Vashem, [interaktyvus], http://collections1.yadvashem. org/notebook_ext.asp?item $=29289 \&$ site $=$ sapir\&lang $=\mathrm{ENG \& menu}=1$, [žiūrèta 2020-08-28].

„Probably Siauliai, Lithuania, Digging of graves before an execution by members of an Einsatzgruppe in the Kuziai Forest", in: Yad Vashem, [interaktyvus], http:// collections1.yadvashem.org/notebook_ext. asp?item $=3017 \&$ site $=$ sapir \&lang $=\mathrm{EN}$ G\&menu=1, [žiūrèta 2020-08-28].

„Probably Siauliai, Lithuania, Digging graves in the Kuziai Forest", in: Yad Vashem, [interaktyvus], http://collections1.yadvashem. org/notebook_ext.asp?item $=59745 \&$ site $=$ sapir\&lang $=\mathrm{ENG \& menu}=1$, [žiūrèta 2020-08-28].

„Probably Siauliai, Lithuania, A German soldier photographing prisoners being led to their execution, 1941“, in: Yad Vashem, [interaktyvus], http://collections1.yadvashem. org/notebook_ext.asp?item $=78963 \&$ site $=$ sapir\&lang $=$ ENG\&menu $=1$, [žiūrèta 2020-08-28].

Shneer David, „Picturing Grief: Soviet Holocaust Photography at the Intersection of History and Memory“, in: American Historical Review, 2010, Nr. 1(115), p. 28-52, [interaktyvus], https://academic.oup.com/ ahr/article-abstract/115/1/28/17666, [žiūrèta 2017-12-04]. 
Shneer David, Through Soviet Jewish Eyes: Photography, War and the Holocaust, New Brunswick: Rutgers University Press, 2010.

Struk Janina, Photographing the Holocaust: Interpretations of the Evidence, London: I. B. Tauris, 2004.

Sutton Karen, The Massacre of the Jews of Lithuania: Lithuanian Collaboration in the Final Solution, 1941-1944, Jerusalem: Gefen Publishing House, 2008.

Tagg John, The Burden of Representation: Essays on Photographies and Histories, Basingstoke: Palgrave Macmillan, 1988.

Terleckas Vladas, The Tragic Pages of Lithuanian History (1940-1953), Vilnius: Petro ofsetas, 2014.

The Encyclopedia of Jewish Life Before and During the Holocaust, sud. Shmuel Spector, Geoffrey Wigoder, New York: New York University Press, 2001.

„The execution of a Jewish woman in the Kalevi-Liiva extermination site in Estonia“, in: Ghetto Fighters House Archives, [interaktyvus], http://www.infocenters. co.il/gfh/notebook_ext.asp?item $=1090 \&$ site $=$ gfh\&lang $=\mathrm{ENG \& menu}=1$, [žiūrèta 2020-08-28].

„The Good Old Days“: The Holocaust as Seen by Its Perpetrators and Bystanders, ed. Ernst Klee, Willi Dressen, Volker Riess, trans. Deborah Burnstone, foreword by Hugh R. Trevor-Roper, New York: The Free Press, 1991.

The Phototheque, [interaktyvus], http://www. memorialdelashoah.org/en/archives-and-documentation/the-documentation-center/ the-phototheque.html, [žiūrèta 2020-08-28].

The Pictorial History of the Holocaust, sud. Yitzhak Arad, Jerusalem: Yad Vashem, 1990.

The Shoah (Holocaust) in Lithuania, sud. Joseph Levinson, Vilnius: Valstybinis Vilniaus Gaono žydų muziejus, 2007.

„The visual evidence of the murder of the Jews of Liepaja“, in: Yad Vashem, [interaktyvus], http://www.yadvashem.org/righteous/ stories/sedul-schimelpfening/liepaja-murder-evidence.html, [žiūrèta 2020-08-28].

Tumavičiūtè Irena, „Kodèl serbų žudynès iliustruoja „MŪSIŠKIUS“?“", in: Voruta, 201604 05, [interaktyvus], http://www. voruta.lt/irena-tumaviciute-kodel-serbu-zudynes-iliustruoja-musiskius-2/, [žiūrèta 2020-08-28].

Vanagaitè Rūta, Mūsiškiai, Vilnius: Alma littera, 2016.

Zelizer Barbie, „Introduction: On Visualizing the Holocaust", in: Visual Culture and the Holocaust, sud. Barbie Zelizer, London: Rutgers University Press, 2001, p. 1-10.

Žeimantas Vytautas, Teisingumas reikalauja, Vilnius: Valstybinè politinès ir mokslinès literatūros leidykla, 1984.

Žydu gyvenimas Lietuvoje = Jewish life in Lithuania: Parodos katalogas, sud. Rūta Puišytè, Darius Staliūnas, Vilnius: Valstybinis Vilniaus Gaono žydų muziejus, 2001.
99 2020

Acta Academiae Artium Vilnensis 


\title{
Photographic Representations of the Holocaust in Lithuanian Historiography: General Features and Problematic Aspects
}

\author{
Šarūnẻ Sederevičiūtè
}

Keywords: Holocaust, photography, Lithuanian history, historiography.

The research presented in the article explores the features and use of historical photographs chosen to represent the Holocaust in Lithuania in Lithuanian and international historiography, including popular literature. Referring to the theoretical literature on Holocaust photography, critical areas of Holocaust photography are outlined, and images found in the historiography of the Lithuanian Holocaust are systemized accordingly. Secondly, by analyzing different categories (the photographer's identity, topic, event, subject, location, caption type, archival source), photographs from Lithuanian and international publications are compared. Finally, the main critical aspects of the publication of photographs representing the Holocaust in Lithuania are identified and discussed, paying special attention to the issues of their iconic properties and authenticity.

The results of the presented research show an obvious necessity for historical research on the circumstances of the emergence of Holocaust photography and its dissemination in later times. A superficial approach to historical photographic sources is evident from abstract, laconic and sometimes even erroneous captions, the failure to indicate the original circumstances of the appearance of specific images, omitting the photographer's name or the archival source. Other aspects of photographic representations of the Holocaust worth mentioning are a strong countertrend to the prevailing perpetrator perspective, the predominance of images from Kaunas, and the prominence of the topic of ghetto life. This situation is mostly a result of 
the wide circulation of photographs taken by the Kaunas ghetto inmate Zvi Hirsh Kadushin (1910-1997) both in Lithuania and abroad.

Pilot rather than conclusive, the present research aims to map out the main topics for the future research on Holocaust photography in Lithuania. 